\title{
Developing biomimicry STEM activity by querying the relationship between structure and function in organisms
}

\author{
Ayşe Savran Gencer ${ }^{(D)}$ \\ Pamukkale University, Faculty of Education, Denizli, Turkey, asavran@ pau.edu.tr \\ Hilmi Doğan \\ Ministry of National Education, Yeniköy Middle School, Antalya, Turkey, hilmi_dogan@msn.com \\ Kadir Bilen ${ }^{(D)}$ \\ Alanya Alaaddin Keykubat University, Faculty of Education, Antalya, Turkey, kadir.bilen@alanya.edu.tr
}

ABSTRACT The theme that structure determines function is one of the most significant cornerstones in understanding natural sciences. On the other hand, recently revised science curriculum in Turkey has emphasized science and engineering practices to help students be able to converge science with the other disciplines by applying theory into practice and product; but there is not an emphasis on the repeating patterns and relationships between structure and function for natural and built systems at any grades. In order to close this gap, the main objective of this study is to develop an integrated biomimicry STEM activity about the unit of Living Things World at grade five. This paper reported on a case study of 21 fifth-grade students' gaining experiences about the engineering design process by mimicking a structure from the organisms to solve a human problem. Even more striking result is that students can manage to incorporate biomimicry into their design solutions by the way of complementary relationship between structure and function in organisms.

Keywords: Biomimicry, Design, Function, STEM Education, Structure

\section{Organizmalarda bulunan yapı fonksiyon ilişkisi sorgulanarak biyomimikri STEM etkinliği geliştirilmesi}

ÖZ Doğa bilimlerini anlamada en önemli mihenk taşlarından biri yapı fonksiyonu belirler temasıdır. Diğer taraftan Türkiye'de yakın zamanda revize edilen fen programında ise öğrencilerin feni diğer disiplinlerle bütünleştirerek teoriyi pratiğe ve ürüne dönüştürebilmelerine yardımcı olacak fen ve mühendislik uygulamalarına vurgu yapılırken; doğada ya da tasarlanmış dünyada tekrar eden örüntülere ve yapı ve işlev arasındaki ilişkilere herhangi bir sınıf düzeyinde vurgu yapılmamıştır. Bu açığı kapatmak için çalışmada, beşinci sınıf fen bilimleri dersi Canlılar Dünyası ünitesinde yapı ve fonksiyon ilişkisine dayanan bütünleştirilmiş biyomimikri STEM etkinliği geliştirmek amaçlanmıştır. Bu çalışma, 21 beşinci sınıf öğrencisinin insanlığa ait bir problemi çözmek için organizmalara ait bir yapıyı taklit ederek mühendislik tasarım süreci ile ilgili deneyimlerini aktaran bir durum çalışmasıdır. Çalışmanın çarpıcı bir sonucu ise, öğrencilerin organizmalardaki yapı ve fonksiyon arasındaki tamamlayıcı ilişki yoluyla biyomimikriyi tasarım çözümlerine dahil etmeyi başarabilmeleridir.

Anahtar Sözcükler: $\quad$ Biyomimikri, Fonksiyon, STEM Ĕ̈itimi, Tasarım, Yapı 


\section{INTRODUCTION}

The understanding of the relationship between structure and function has been recognized both as a crosscutting and disciplinary core concepts in the current reform document of A Framework for $\mathrm{K}-12$ Science Education: Practices, Crosscutting Concepts, and Core Ideas (Framework) (National Research Council [NRC], 2012). Amongst the seven crosscutting concepts as unifying themes across all the disciplines and grade levels, structure and function are defined as "the way in which an object or living thing is shaped and its substructure determine many of its properties and functions" (NRC, 2012, p. 84). The theme that structure determines function is one of the most significant cornerstones in understanding natural sciences. Structure is the way that an organism is shaped as a whole. Functions are the processes that help an organism to survive. The structure and function of an organism work complementarily in nature to meet the needs of the organism. Understanding these causal relationships between structure and function through the identification of mechanisms like behaviors in life sciences can be delineated by Structure-Behavior-Function (SBF) theory. The SBF theory makes it explicit how structure and function causally related with a bridge of behaviors/actions (Hmelo, Holton, \& Kolodner, 2000; Hmelo-Silver, Marathe, \& Liu, 2007). In this way, the SBF theory may account for coherent science learning in providing students to understand the purposes and processes of the structures to achieve their function (Hmelo-Silver et al., 2008). Also, when biological function is used in the same meaning as adaptation, it may account for understanding the origin of a structure's function that emerged in the evolutionary process (Kohn, Underwood, \& Cooper, 2018).

As related to the extent in which students understand the functions of structures by querying organisms or molecules in the natural world requires making causal inferences. This is a similar way by which "engineers make such inferences when examining structures in nature as inspirations for designs to meet people's needs" (Next Generation Science Standards [NGSS] Lead States, 2013b, p.89). Engineers learn from studying nature; so they observe nature to get brilliant ideas for design solutions to solve human problems. This explains why technological tools we use in our daily life usually work in the same way as something in nature. As it can be seen that "the functioning of natural and built systems alike depends on the shapes and relationships of certain key parts as well as on the properties of the materials from which they are made" (NRC, 2012, p.96). Such scientific explanations of the relation between structure and function in natural systems can be further delineated by mimicking the translation of these observations into design solutions to solve human problems for STEM (Science, Technology, Engineering, and Mathematics) education. Therefore, understanding the purpose or mechanical function of structures in nature as a learning outcome in science courses should be considered in STEM education.

STEM education proposes an interdisciplinary integration of knowledge, skill, and beliefs relate to more than one STEM disciplines through the collaborative efforts of students and teachers (Çorlu, Capraro, \& Capraro, 2014; Öner et al., 2014). To accomplish this goal, engineering and engineering design process-oriented integration for science teaching has been appreciated in the current reform documents (e.g., NRC, 2012) and related literature (e.g., Guzey, Thank, Wang, Roehrig, \& Moore, 2014; Moore et al., 2014). Amongst the scope of Integrated Teaching Framework (ITP), which is considered as an effort for the pedagogical interpretation of STEM for Turkish context, the methodological integration means to use both the discipline and the methods of a particular field education in the teaching of other fields depending on the interests of teachers and students. The four main principles of integrated STEM education are defined as equity, relevance, interdisciplinarity and rigor (Aşık, Doğança Küçük, Helvacı \& Çorlu, 2017). In parallel to this pedagogy as proposed by Aşık et al., (2017), the current study is an example for the use of the engineering design process or engineering-based learning in science classes. 


\section{Structure and Function as a Crosscutting and Core Concept}

The Framework (NRC, 2012) defines crosscutting concepts as to "bridge disciplinary boundaries, having explanatory value throughout much of science and engineering" (p. 83). These concepts provide students useful lenses for recognizing similarities among disciplinary core ideas and practices in science and engineering. Thus, crosscutting concepts are common themes emerging across all science and engineering disciplines to help students better understand phenomena. As the NGSS document points out, there is no need to teach and assess these concepts as a separate vocabulary from practices or disciplinary context. Rather, the crosscutting concepts should be embedded in the science curriculum from beginning in the early grades of schooling and growing in complexity and sophistication across the grades (NGSS Lead States, 2013b).

The relationship between structure and function as a crosscutting concept can sometimes be essential to make causal inferences as a special case of cause and effect (NGSS Lead States, 2013b). Table 1 indicates that exploration of the relationship between structure and function should begin in the early grades and progress in complexity across the grades both as crosscutting and disciplinary core concepts. In early grades students can relate the shape and stability of structures for a variety of functions like a bridge's diagonal brace or mechanical function such as wheels, axles, and gears. As students' progress through the upper grades they are expected to improve from recognizing particular structures or substructures observed in the visible systems to a more complex, small scale, non- visible systems are related to their functions (NRC, 2012).

Table 1.

Progression of ideas for the structure and function both as a crosscutting concept and disciplinary core idea (Adapted from Duschl, 2012; NGSS Lead States, 2013b)

\begin{tabular}{cll}
\hline Grades & Structure and function as a crosscutting concept & Structure and function as a core idea in the life sciences \\
\hline K-2 & $\begin{array}{l}\text { Examine relationships of structure and function in } \\
\text { accessible and visible natural and human built } \\
\text { systems. }\end{array}$ & $\begin{array}{l}\text { All organisms have external parts that they use to perform } \\
\text { daily functions. }\end{array}$ \\
$\begin{array}{l}\text { Matter has a substructure that is related to properties } \\
\text { of materials. Begin study of more complex systems } \\
\text { by examining subsystems and the relationships of the } \\
\text { parts to their functions. }\end{array}$ & $\begin{array}{l}\text { Organisms have both internal and external macroscopic } \\
\text { structures that allow for growth, survival, behavior, and } \\
\text { reproduction. }\end{array}$ \\
$\begin{array}{l}\text { Visualize, model, and apply understandings of } \\
\text { structure and function to more complex and less } \\
\text { easily observable systems and processes. The concept } \\
\text { of matter having submicroscopic structures is related } \\
\text { to properties of matter. }\end{array}$ & $\begin{array}{l}\text { All living things are made up of cells. In organisms, cells } \\
\text { work together to form tissues and organs that are } \\
\text { specialized for particular body functions. }\end{array}$ \\
$\begin{array}{l}\text { investigating unfamiliar phenomena; when building } \\
\text { something or deciphering how a system works, begin } \\
\text { with examining what it is made of and what shapes its } \\
\text { parts take. }\end{array}$ & $\begin{array}{l}\text { Systems of specialized cells within organisms help } \\
\text { perform essential functions of life. Any one system in an } \\
\text { organism is made up of numerous parts. Feedback } \\
\text { mechanisms maintain an organism's internal conditions } \\
\text { within certain limits and mediate behaviors. }\end{array}$ \\
\hline
\end{tabular}

In this respect, understanding the structure and function as a topic for the life sciences should be emphasized as well. Bybee (2013) states the main goal of biology as to "develop explanations for functions based on structures and reciprocal-to explain the complementarity of structures and functions among an organism's systems and subsystems" (p.26). Likewise, the life sciences (LS) in the Framework focus on patterns, processes, and relationships of living organisms. The first core idea 'LS1: From molecules to organisms: Structures and processes' addresses the characteristic structures of organisms to live, grow, respond to their environment, and reproduce. As the first subcomponent 'LS1.A: Structure and function' explains how the structures of organisms enable life's functions by beginning from cells as the basic structural units to structural systems and subsystems of organisms that perform specialized functions (NRC, 2012). As it can be seen in Table 1, students at elementary grades are expected to investigate the relationships between the external and internal structures of organisms and their functions in growth, survival, behavior, and reproduction at the macroscale systems. Students in middle grades are expected to investigate explanations for the structure and function of cells as the basic units of life at microscale systems. Students at higher levels demonstrate 
an understanding of how systems of cells function together to support the life processes, the hierarchical systems of organisms, and the role of specialized cells for maintenance and growth.

\section{Why Teach Biomimicry?}

The term biomimicry originates from Greek roots bios that means life and mimicry that means to imitate. Beyond its simple meaning of imitation of life, biomimicry is defined as "a creative form of technology that uses or imitates nature to improve human lives" (Hwang et al., 2015, p.5701). The origin of the term coined as biomimetics, bionics, bio-inspired design that are all used usually in the same meaning in the scientific literature. It has been considered as a new discipline of science starting from the book of Janine Benyus's in 1997 titled "Biomimicry: Innovation Inspired by Nature". In her book, biomimicry is defined as "a new science that studies nature's models and then imitates or takes inspiration from these designs and processes to solve human problems e.g., a solar cell inspired by a leaf" (Benyus, 2002, p.0). In other words, biomimicry as an approach "seeks sustainable solutions to human challenges by emulating nature's time-tested patterns and strategies" (Biomimicry Institute, 2010). According to Benyus (2002) billions of years of evolutionary process have given living organisms an amazing diversity of structures, shapes and their related functions to survive. Thus, learning from studying nature for perfection, accuracy and sustainability of natural mechanisms is the underlying philosophy of Benyus's theory of biomimicry.

There are well known examples of biomimicry in the history of human industrialization like Leonardo da Vinci's (1452-1519) work designed a "flying machine" by mimicking a bird and Wright brothers' (1867-1948) airplane designed by mimicking the wings of eagles. Nowadays, transportation vehicles may become faster, more stable, and more aerodynamic but still nature gives inspiration like Japanese bullet train mimicking a kingfisher's beak to reduce sonic boom and air resistance. It can be seen that biomimetic technology is applied in many different fields including material science, robotics, nanotechnology, product, design, innovation, inventions, systems design, architecture, agriculture, chemistry, medicine, communication and mechanics. One of the best known product examples of biomimicry is Velcro, a common hook-and-loop fastener, invented in 1948 by Swiss engineer George de Mestral who inspired from the fruit of the burr that sticks to his clothes and his dog's fur while hiking (Hwang et al., 2015; Pauw, Kandachar, Karana, Peck, \& Wever, 2010).

There are three levels to mimic a natural system as regard to the increasing complexity from the organism level, to behavior level and ecosystem level. Biomimicry at the organism level indicates the mimicry of a specified organism or a part from the whole organism. Biomimicry at the behavior level indicates the mimicry of behavior in a specified organism. Biomimicry at the ecosystem level indicates the mimicry of whole ecosystem. At each level biomimicry can take place as a form about how it looks, material about what it is made from, construction about how it is made, process about how it works, and function about what is the capability. For example, building that mimics termites in architecture is a good representative of three levels and their sub-dimensions. At the organism level the building looks like a termite. At the behavior level the building looks like such a termite mound that is made by termites. At the ecosystem level the building looks like an ecosystem such termites would live in (Aziz \& El sherif, 2016).

While learning from studying nature there are two main approaches suggested for a biomimicry design process as indicated in Figure 1. Top-down approach or challenge to biology begins with an identified human need or problem and then looks intentionally into nature how organisms or ecosystems solve this problem for better design solutions. Conversely, bottom-up approach or biology to design begins by examining nature to identify a particular structure, behavior or function belongs to an organism or ecosystem for transmitting this bio-inspired design solution into a human problem (Aziz \& El sherif, 2016). 


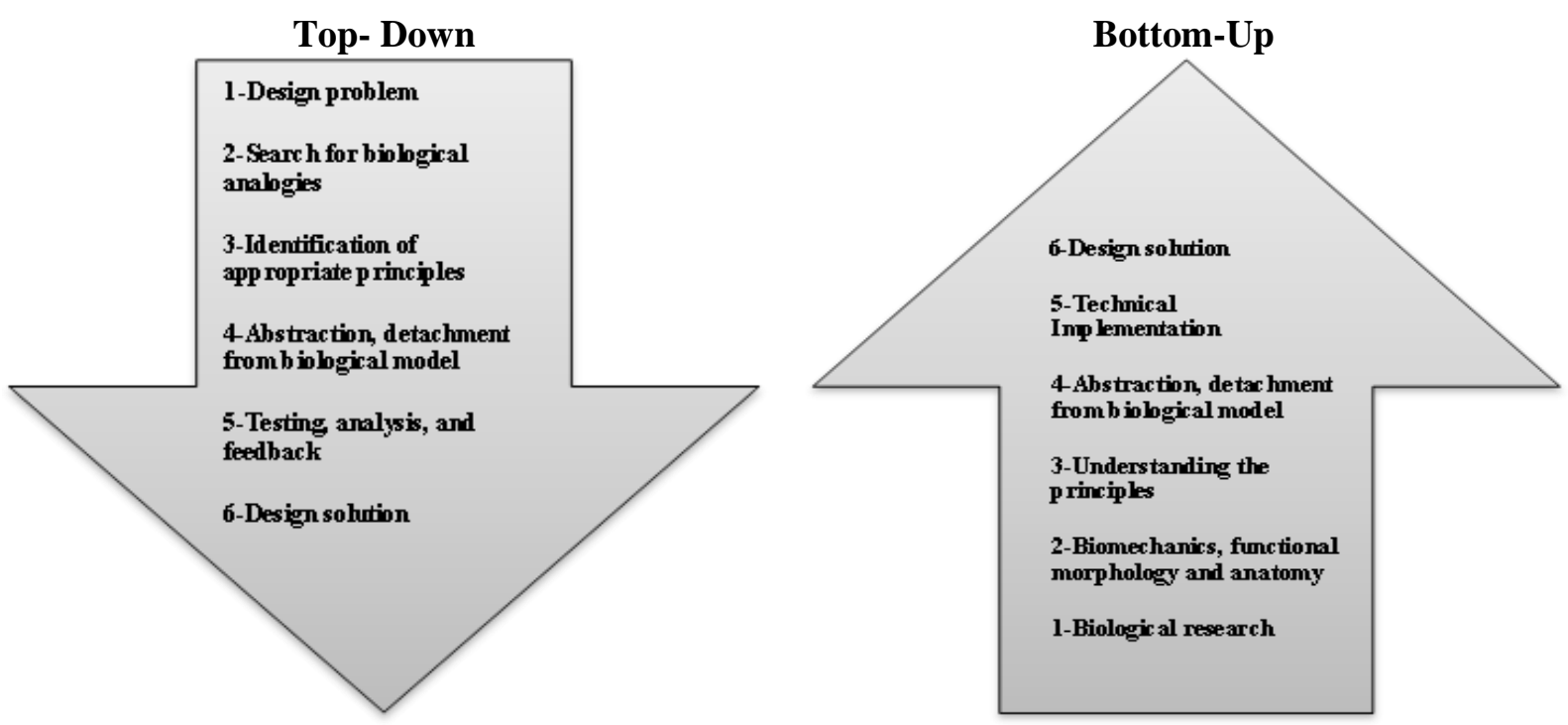

Figure1. Biomimicry top-down and bottom-up approaches (Adapted from Aziz \& El sherif, 2016)

It is inevitable that using nature as a model for sustainable design solutions has initiated the conceptualization of biomimicry in science education. Biomimicry can be viewed as a revolution in education by offering teachers a way to inspire students of all ages by blending life sciences, STEM, creative problem solving, design, and systems thinking (Biomimicry Institute, 2010). Teaching biomimicry in STEM education can provide a context by intersecting nature with science, technology, engineering and math. Consequently, being inspired by nature requires understanding how nature works by identifying various functional and environmental adaptation mechanisms of organisms and their sustainability in basic science courses at early stages.

\section{Rationale for the Study}

As proposed in the Framework when the students develop an understanding about the relationships between structure and function, they can apply this knowledge to learn an unfamiliar scientific phenomenon and solve how a system work as a critical element of successful engineering designs (NRC, 2012). Similarly, recently revised science curriculum in Turkey has emphasized science and engineering practices to help students be able to converge science with the other disciplines by applying theory into practice and product; but there is not an emphasis on the repeating patterns and the relationships between structure and function for natural and built systems at any grades (Ministry of National Education [MoNE], 2018). On the other hand, students are expected to classify living things according to their similarities and differences as microscopic organisms, fungi, plants, and animals within the context of the unit of Living Things World at grade five. In order to close this gap in science education, the main objective of this study is to develop integrated biomimicry STEM activity based on the relationship between structure and function in organisms both as an engineering design principle and core component of life sciences for fifth graders to achieve learning outcomes about the classification of living things. In the line with this main aim, the research questions are: (a) How students develop a deep understanding of structure and function about living things? (b) How students develop a deep understanding about the role of biomimicry in engineering design principles?

For this purpose the performance expectations related to the topic of structure and function in the life sciences from the NGSS were adapted to develop biomimicry STEM activity. NGSS Lead States (2013a) emphasizes biomimicry as a performance expectation linked to the structure and function as one of the main component ideas in the life sciences of the first grade numbered as 1-LS1-1 and fourth grade numbered as 4-LS1-1 as indicated in Figure 2. The Figure 2 displays examples of performance expectations for elementary school life sciences with supporting content from the foundation box which combines practices, core ideas and crosscutting concepts. 
PERFORMANCE EXPECTATIONS

Students who demonstrate understanding can:

4-LS1-1. Construct an argument that plants and animals have internal and external structures that function to support survival, growth, behavior, and reproduction. [Clarification Statement: Examples of structures could include thorns, stems, roots, colored petals, heart, stomach, lung, brain, and skin.] [Assessment Boundary: Assessment is limited to macroscopic structures within plant and animal systems.]

1-LS1-1. Use materials to design a solution to a human problem by mimicking how plants and/or animals use their external parts to help them survive, grow, and meet their needs.* [Clarification Statement: Examples of human problems that can be solved by mimicking plant or animal solutions could include designing clothing or equipment to protect bicyclists by mimicking turtle shells, acorn shells, and animal scales; stabilizing structures by mimicking animal tails and roots on plants; keeping out intruders by mimicking thorns on branches and animal quills; and, detecting intruders by mimicking eyes and ears.]

\section{Science and Engineering Practices \\ Engaging in Argument from Evidence}

Engaging in argument from evidence in $3-5$ builds on $\mathrm{K}-2$ experiences and progresses to critiquing the scientific explanations or solutions proposed by peers by citing relevant evidence about the natural and designed world(s). (4LS1-1)

Construct an argument with evidence, data, and/or a model.

Obtaining, Evaluating, and Communicating Information

Obtaining, evaluating, and communicating information in $\mathrm{K}-2$ builds on prior experiences and uses observations and texts to communicate new information.

Read grade-appropriate texts and use media to obtain scientific information to determine patterns in and/or evidence about the natural world. (4-LS1-1)

\section{Constructing Explanations and Designing Solutions}

Constructing explanations and designing solutions in $\mathrm{K}-2$ builds on prior experiences and progresses to the use of evidence and ideas in constructing evidence-based accounts of natural phenomena and designing solutions.

Make observations (firsthand or from media) to construct an evidence-based account for natural phenomena. (4-LS11)

Use materials to design a device that solves a specific problem or a solution to a specific problem. (1-LS1-1)

\section{LS1.A: Structure and Function}

Plants and animals have both internal and external structures that serve various functions in growth, survival, behavior, and reproduction. (4-LS1-1)

\section{LS1.A: Structure and Function}

All organisms have external parts. Different animals use their body parts in different ways to see, hear, grasp objects, protect themselves, move from place to place, and seek, find, and take in food, water and air. Plants also have different parts (roots, stems, leaves, flowers, fruits) that help them survive and grow. (1-LS1-1)

\section{LS1.D: Information Processing}

Animals have body parts that capture and convey different kinds of information needed for growth and survival. Animals respond to these inputs with behaviors that help them survive. Plants also respond to some external inputs. (1-LS1-1)

\section{ETS1.A: Defining and Delimiting an Engineering Problem}

Asking questions, making observations, and gathering information are helpful in thinking about problems. (1-LS1-1)

\section{ETS1.B: Developing Possible Solutions}

Designs can be conveyed through sketches, drawings, or physical models. These representations are useful in communicating ideas for a problem's solutions to other people. (1-LS1-1) ETS1.C: Optimizing the Design Solution

Because there is always more than one possible solution to a problem, it is useful to compare and test designs. (1LS1-1)

\section{Crosscutting Concepts}

Patterns

Patterns in the natural and human designed world can be observed, used to describe phenomena, and used as evidence. (4-LS1-1)

\section{Structure and Function}

The shape and stability of structures of natural and designed objects are related to their function(s). (1-LS1-1)

Systems and System Models A system can be described in terms of its components and their interactions. (4-LS1-1)

Connections to Engineering, Technology, and Applications of Science

Influence of Science, Engineering and Technology on Society and the Natural World

Every human-made product is designed by applying some knowledge of the natural world and is built using materials derived from the natural world. (1-LS1-1)

Connections to Nature of Science

Scientific Knowledge is Based on Empirical Evidence

Scientists look for patterns and order when making observations about the world. (4-LS1-1)

Science is a human endeavor Science affects everyday life. (1-LS1-1) Most scientist and engineers work in teams. (1-LS1-1)

\footnotetext{
* The performance expectations marked with an asterisk integrate traditional science content with engineering through a practice or disciplinary core idea.
}

Figure 2. The performance expectations for LS1: From molecules to organisms: Structures and processes (Adapted from NGSS Lead States, 2013a) 


\section{METHODOLOGY}

This study employed a case study in which "the researcher develops an in depth analysis of a case, often a program, event, activity, process, or one or more individuals" (Creswell, 2014, p.13). The case involves students' learning experiences by participating in the biomimicry STEM activity about organisms. The participants of the study were 10-11 years old 21 students (11 boys, 10 girls) attending $5^{\text {th }}$ grade at the public lower secondary school in Antalya, Turkey. According to Yıldırım and Şimşek (2016), "if the researcher wants to introduce a new application or a novelty, he/she can identify them by determining one or more of the most typical among a series of case in which this application has been done or has innovativeness (p.120). For this purpose, the study group was determined in line with the typical case sampling which is one of the methods of purposeful sampling (Yıldırım \& Şimşek, 2016) that emerged within the qualitative research tradition.

Biomimicry STEM activity worksheets, reflective open-ended questions, semi-structured interviews, rubrics were utilized in collecting data to evaluate the performances of the students and the effectiveness of the STEM activity. The data collection tools focused on obtaining the data in order to reveal how students develop a deep understanding of structure and function about living things and the role of biomimicry in engineering design principles. Students' learning experiences, difficulties which were experienced and how they overcame these difficulties, likes and dislikes, what they learned and how they worked in a team were investigated.

The qualitative collected throughout students' reflections about the engineering design process on open-ended questions and semi structured interviews, teacher's observations and field notes and participant students' portfolios were evaluated by descriptive analysis. The participant teacher's observations and field notes were used to increase the verification by guiding students' learning and behavior in the process. The abbreviations $\mathrm{T}$ for team, $\mathrm{S}$ for student and numbers were used to introduce the student's team and the student member such that T4.S1 means 4th team 1st student.

\section{Ethical Approval}

The typical case sampling aims to describe and illustrate what is typical to those unfamiliar with the setting, not to make generalized statements about the experiences of all participants (Patton, 2014). Prior to the implementation of the research, the necessary permission was obtained according to board decision, dated 05/02/2019 and 2439445 numbered, from the Research Evaluation and Investigation Committee of the Antalya National Education Directorate. Written informed parental consent forms including options of opt-out and opt-in for their children's participation in the research and collecting data from them were sent home to signature. The students were volunteer and had the signed parental consent forms involved in the study.

\section{Description of Biomimicry STEM Activity}

Biomimicry STEM activity provides students the learning opportunity to explore the relationship between structure and function in organisms both as an engineering design principle and a core component of life sciences for 5th graders in the unit of Living Things World. For this study some parts especially involving structure and function activities are described here in detailed. The activity consists of four main parts for science and engineering practices in parallel to the science standards as described below:

Part 1 - Asking Questions and Defining Problems. A scenario about biomimicry design task is given students (see Appendix 1) to introduce a problem or need for the engineering design task. After completing the next stages students consider how a human problem can be solved by mimicking a 
structure from the organisms that has similar purpose for the engineering design process. Students then identify a human problem and develop their own design solutions inspired by organisms' adaptations.

Part 2 - Engaging in Argument from Evidence. It is expected that students get to know different kinds of organisms, determine the structures belonging to these organisms and explain how these structures help them to continue their lives by utilizing scientific resources or throughout their individual investigations. Using the scientific popular books like published by Scientific and Technological Research Council of Turkey (TUBITAK) titled "First Reading Series: Bees, Elephants, Spiders, Penguins, Bears, Owls, Caterpillars and Butterflies, Dogs, Trees etc." would help students develop an understanding of how particular features help animals and plants to survive. Students then complete the worksheet of Structure and Function as individually given in Appendix 2 to keep the observed structures and their functions in different organisms from different resources. Teachers' use of science talk along within these texts can promote students to obtain scientific information in examining structures and inferring their functions. To reinforce and extend this understanding as a core idea of life sciences teachers can have students engage in constructing arguments that plants and animals have internal and external structures functioning to support survival, growth, behavior, and reproduction with evidence, data, and/or a model. Similarly, as a crosscutting concept of structure and function at this stage it is explicitly emphasized that "the structure or shape of an object or system is frequently related to use, operation, or function. Scientists infer function by referring to form and also explain form by referring to function" (Lederman, 2019).

Part 3 - Obtaining, evaluating, and communicating information. Designing Imaginary Organism activity is given students to enhance the understanding the organisms' adaptations in relation to structure and function. It is expected that students get to design their own imaginary organism within their groups by using the previously gathered data from the observation of organisms' particular structure and their function. They decide structures and their functions that the organisms need to survive by describing their adaptations on the worksheet of Imaginary Organism's Adaptations given in Appendix 3. After they identify their imaginary organisms' structures, feeding type, predators, habitat, physical and behavioral adaptations etc., they draw their imaginary organism on the worksheet of Drawing and Labelling the Imaginary Organism given in Appendix 4 by describing the traits and adaptations on it. By using the worksheet of Introducing Imaginary Organism given in Appendix 5 groups decide the scientific name and other characteristics to classify their organisms. They can also write a story or news about the investigation of their imaginary organism in the given part of Appendix 4. In order to introduce their organism for the rest of the class, groups make the model of their imaginary organism by depicting on one of their friends by using provided materials in the classroom. During the presentation of the model organisms of the groups, students would be asked to present what functions their organisms have and why they interpret particular structures in that way. Another way of presenting the model organisms would be audience students asked to infer what the function might be from the structure of organisms. Students can also be asked why they used particular materials for the structure that they infer. At this moment, it is an appropriate time to discuss the distinction between observation and inference. The structure would directly be observable using our senses, but its function is not directly observable (Lederman, 2019). During the presentations, the teacher evaluates the model organisms that each group has by using the Imaginary Organism Assessment Rubric (see Appendix 6).

Part 4 - Constructing Explanations and Designing Solutions. Students are introduced with the great design task through a scenario given at first that defines biomimicry and how bioengineers inspire nature to develop new ideas for innovations. Using the scientific knowledge and models learned in the previous steps in which students make such observations about animals and plants' adaptations for survival, growth and meeting their needs, they can translate this information in a larger study to design a solution to a human need. In reverse relation, students would be asked to give examples by identifying and comparing designed objects related to natural shapes and structures. This investigation provides students to connect how observations of the natural world aid human survival. Then, they are asked to identify a human problem to develop a possible solution by using biomimicry which may be 
an imitation of the relation between structure and function that belongs to organisms. As bioengineers students draw their prototype design solutions and describe how their design solutions solve the human problem on the worksheet of Great Design Task Draft Drawing given in Appendix 7. After deciding on the best design solution, students are supplied with materials to design a prototype model that solves a specific problem or a solution to a specific problem. In the last step students test, evaluate and analyze their design solutions within their groups to improve their model. Once the process is completed, groups present their biomimicry models in respect to the relations between the design and inspirations from the natural world by providing an analysis of the design process. During the presentations, the teacher evaluates the biomimicry models that each group has by using the Biomimicry Design Task Assessment Rubric (see Appendix 8).

\section{Implication Steps of Biomimicry STEM Activity}

Biomimicry STEM activity was planned to cover all the outcomes about the classification of living things within a larger dissertation study based on engineering design based unit phases (Wendell et al., 2010) and eight step engineering design process of Massachusetts Department of Education (2006). The study was conducted for twelve hours during the science lessons at the first term of the school year of 2018-2019 by the second author of this research. The activity was started with the identification of the need or the problem. During the two-lesson hour, students identified the human need or problem which was given in the scenario. They described the criteria and constraints. After identification of the needs/problem, they were researching the need/ problem in the second step. In this phase, students investigated the scientific knowledge needed for solving the problem phase. During the four-lesson hour, the scientific knowledge collected from books and mini activity, imaginary organism activity implemented to understand structure and functions in nature. Collected scientific knowledge was used for developing possible solutions in the step three. During the one-lesson hour, students developed solutions individually in their team for the one-hour lesson. They explained their solution proposals by using criteria and constraints. The developed possible solutions were discussed in their team in order to choose the best solution proposal. In the step of selecting the best possible solution, students used a decision-making matrix to decide the best one by using criteria and constraints during the one-lesson hour. The chosen solution by the team used for constructing a model/prototype in the step five. In this period, students developed their models in the two-lesson hour. Developed models were tested/controlled by using a checklist according to the criteria and constraints in the step of test and evaluate the solution after then they presented their models in the phase of communicate the solution during the one-lesson hour. In the last step of redesign, each team improved its solutions regarding the feedback from teacher and students during the one-lesson hour.

\section{Description of Performance Assessment Rubrics}

The Imaginary Organism Assessment Rubric (see Appendix 6) was developed for assessing the models that students developed to describe their imaginary organisms' adaptations based on the mechanism between structure and function on the range of 0 and 24 points. The first sub-dimension of the rubric titled Developing and Using Models indicates the progression of students from level 0 to 3 for developing an accurate model in terms of drawing, description and identification of their imaginary organisms. The second sub-dimension of the rubric titled Structure and Function indicates the progression of students from level 0 to 3 for accurately explaining the relation between proposed structure and function that an imaginary organism has for each adaptation.

The Biomimicry Design Task Assessment Rubric (see Appendix 8) was developed for assessing the prototype biomimicry models that students developed to solve a human problem as regards to eight categories that indicates the progression of students from level 0 to 3 providing analysis of the engineering design process on the range of 0 and 48 points. The categories of the rubric developed based on the engineering design steps of Massachusetts Science and Technology/Engineering Curriculum Framework (Massachusetts Department of Education, 2006) in order to assess students' achievement on engineering design steps. 


\section{Description of Evaluation Form}

Biomimicry STEM Activity Reflective Evaluation Form (see Appendix 9) consists of open-ended questions to realize students' perceptions and opinions about the whole process of engineering design task. The form was applied for all the students of 21 at the end of the study. Six students were interviewed with the similar questions because of their short or unclear answers.

\section{FINDINGS}

\section{Findings on the Imaginary Organism Assessment Rubric}

Through the science activities as performance expectations, students are expected to query the structures of organisms and relate their functions, create an imaginary organism, and communicate the way of thinking by drawing, labeling, and explaining. Students developed an imaginary model organism by describing the traits and adaptations on it as well as by describing its scientific group and scientific name. The drawings and created imaginary organisms that each group developed are displayed in Appendix 10. The Imaginary Organism Assessment Rubric was used for assessing students' science learning through the worksheets completed during the whole process and created imaginary model organisms' adaptations. After each group presented their imaginary model organism, the teacher completed the rubric. The Table 2 indicates the overall score that each group gets for their imaginary model organism. As regard to the table each team has average high score that indicates students' understanding the role of the structure-function relationship in organisms' adaptations. When the presented imaginary organisms were considered, students were able to describe their organisms' structures, feeding type, predators, and habitat, physical and behavioral adaptations.

Table 2 .

Imaginary organism assessment rubric scores

\begin{tabular}{clcccccc}
\hline \multicolumn{1}{c}{ Dimension } & \multicolumn{1}{c}{ Criteria } & Team 1 & Team 2 & Team 3 & Team 4 & Team 5 & Team 6 \\
\hline \multirow{3}{*}{ Developing and using models } & Name and classification & 3 & 3 & 2 & 3 & 2 & 1 \\
& Drawings & 2 & 2 & 2 & 3 & 2 & 3 \\
& Description & 3 & 3 & 3 & 3 & 3 & 3 \\
& Nutrition & 3 & 3 & 2 & 3 & 3 & 3 \\
\multirow{5}{*}{ Structure and Function } & Defending from predators & 2 & 3 & 2 & 3 & 3 & 3 \\
& Communication & 2 & 2 & 3 & 3 & 2 & 3 \\
& Mating & 0 & 3 & 2 & 2 & 3 & 3 \\
\hline Total Score & Habitat & 2 & 3 & 3 & 3 & 3 & 3 \\
\hline
\end{tabular}

\section{Findings on the Biomimicry Design Task Assessment Rubric}

Through the engineering design activities as performance expectations, students are expected to describe how they would adapt an organism's structure to solve a human problem. Appendix 11 displays the sample drawings of great designs for the biomimicry models that each group proposed to solve a human problem. The biomimicry models that each group developed are displayed in Appendix 12. The Biomimicry Design Task Assessment Rubric was used to evaluate the students' prototype biomimicry models at eight categories. After each team presented their biomimicry designs to the class, the teacher completed the rubric. Table 3 indicates the scores for eight categories and for overall that each group has for their biomimicry model. The students' scores on the categories of 'Identify the need or the problem' including identifying constraint and criteria and 'Research the need or the problem' are lower than other steps of the engineering design process. Although all groups have the lowest score in identifying and research the problem, they seem to develop an understanding about engineering design as a whole process. When the developed biomimicry models were considered, they 
were able to reflect the complementary relationship between structure and function in relation to the behaviors of organism in their design solutions for a human problem. The Team 1's biomimicry model named as fishing-net aims to help people fish inspired from pelican's beak. The Team 2's biomimicry model named as non-slip socks aims to prevent people from slipping inspired from gecko's toe pads. The Team 3's biomimicry model named as trap aims to help people hunt inspired from Venus flytrap. The Team 4's biomimicry model named as bat's ear headset aims to help deaf people hear or use in sound insulation inspired from bat's ears. The Team 5's biomimicry model named as hook aims to help people carry out heavy things inspired from falcon's claw. The Team 6's biomimicry model named as sew-burry aims to help people plant seed easily inspired from chicken's beak.

Table 3.

The biomimicry design task assessment rubric scores

\begin{tabular}{|c|c|c|c|c|c|c|c|}
\hline $\begin{array}{l}\text { Engineering Design } \\
\text { Process } \\
\end{array}$ & Criteria & $\begin{array}{c}\text { Team } \\
1\end{array}$ & $\begin{array}{l}\text { Team } \\
2\end{array}$ & $\begin{array}{c}\text { Team } \\
3\end{array}$ & $\begin{array}{c}\text { Team } \\
4\end{array}$ & $\begin{array}{c}\text { Team } \\
5\end{array}$ & $\begin{array}{c}\text { Team } \\
6\end{array}$ \\
\hline \multirow{3}{*}{$\begin{array}{l}\text { Identify the need or } \\
\text { the problem }\end{array}$} & Identification of need/problem & 2 & 1 & 2 & 2 & 3 & 2 \\
\hline & Identification criteria and constraints & 1 & 1 & 1 & 1 & 1 & 2 \\
\hline & $\begin{array}{l}\text { Identifying the information needed to solve } \\
\text { the need / problem }\end{array}$ & 1 & 1 & 2 & 2 & 1 & 1 \\
\hline $\begin{array}{l}\text { Research the need } \\
\text { or the problem }\end{array}$ & $\begin{array}{l}\text { Identifying how the information obtained } \\
\text { will be used to solve a human needs / } \\
\text { problem }\end{array}$ & 1 & 1 & 2 & 1 & 1 & 2 \\
\hline \multirow{3}{*}{$\begin{array}{l}\text { Develop possible } \\
\text { solution(s) }\end{array}$} & Suggestion of solution for needs / problem & 1 & 1 & 3 & 2 & 1 & 3 \\
\hline & Drawing blueprint for solution proposal & 2 & 2 & 2 & 2 & 2 & 3 \\
\hline & $\begin{array}{l}\text { Determining the pros and cons of solution } \\
\text { proposals } 11\end{array}$ & 1 & 1 & 2 & 2 & 2 & 3 \\
\hline $\begin{array}{l}\text { Select the best } \\
\text { solution(s) }\end{array}$ & $\begin{array}{l}\text { Explanation of the reasons (positive } \\
\text { /negative aspects, criteria and constraints) of } \\
\text { the selection the best proposal }\end{array}$ & 1 & 1 & 2 & 2 & 2 & 2 \\
\hline \multirow{2}{*}{$\begin{array}{l}\text { Construct a } \\
\text { prototype }\end{array}$} & $\begin{array}{l}\text { Building a model / prototype for the solution } \\
\text { proposal }\end{array}$ & 2 & 2 & 3 & 3 & 2 & 3 \\
\hline & $\begin{array}{l}\text { Using the materials that meet the criteria and } \\
\text { constraints for the model / prototype }\end{array}$ & 3 & 3 & 3 & 3 & 3 & 2 \\
\hline \multirow{2}{*}{$\begin{array}{l}\text { Test and evaluate } \\
\text { the solution(s) }\end{array}$} & $\begin{array}{l}\text { Testing how the model or prototype solves } \\
\text { the problem/need }\end{array}$ & 1 & 2 & 3 & 3 & 2 & 3 \\
\hline & $\begin{array}{l}\text { Explanation of the test results using a } \\
\text { scientific language }\end{array}$ & 1 & 2 & 3 & 2 & 2 & 2 \\
\hline \multirow[b]{2}{*}{$\begin{array}{l}\text { Communicate the } \\
\text { solution(s) }\end{array}$} & $\begin{array}{l}\text { Explaining how designs can solve human } \\
\text { needs / problems }\end{array}$ & 2 & 2 & 3 & 2 & 2 & 3 \\
\hline & $\begin{array}{l}\text { Determining the structures of living things in } \\
\text { their designs and how they are used in their } \\
\text { functions }\end{array}$ & 1 & 2 & 3 & 2 & 2 & 3 \\
\hline \multirow[b]{2}{*}{ Redesign } & $\begin{array}{l}\text { Describing the required improvements for } \\
\text { their design }\end{array}$ & 2 & 2 & 3 & 2 & 2 & 2 \\
\hline & $\begin{array}{l}\text { Improving designs according to the data and } \\
\text { evaluations obtained as a result of testing } \\
\text { and sharing solutions }\end{array}$ & 1 & 2 & 3 & 2 & 1 & 2 \\
\hline Total Score & $\ldots / 48$ & 23 & 26 & 40 & 33 & 29 & 38 \\
\hline
\end{tabular}

\section{Findings on the Reflective Evaluation Form}

The prominent findings on the examination of the students' reflection by applying open-ended questions and semi-structured interviews about the activity are summarized under the four themes as following; challenges, team working, learning in activity, and likes and dislikes. The students expressed that they faced with the challenges while building their model/prototype $(n=11)$ and team working such as indecisions $(n=4)$ and disputes $(n=2)$ within the team $(n=9)$, and the selection of the best solution $(n=3)$. Students usually expressed difficulties while practicing the mechanism in their model. For example, one of the students reported that "the mechanism inside our design that is the point we had difficulty choosing which material to use" (T6.S4). As an example for group challenges T1.S6 reported that "We had a lot of difficulty because each design solution was very good" Similarly, T2.S2 reported that "We could not make a decision in the team." Another student member in the same group explained the reason for the problems that they had faced in the group work as "Because we 
have a lot of ideas in our mind. Which one we should apply? Which one is more beautiful? Which one works well? So, we had some confusion in the group" (T2.S1).

On the other hand, they explained how they overcome the challenges while working within team members including collaborating, brainstorming, generating new ideas, discussing, helping each other and finding a solution together $(\mathrm{n}=11)$. For example, T3.S3 stated that "Two friends in our group did not work well at the first. They were working as if they had been in another group. It frustrated me. We could not work well. But we had an agreement with them. After agreement we would work together harder." Besides they expressed that using different materials $(\mathrm{n}=1)$, by trying $(\mathrm{n}=1)$, planning study $(n=1)$, using criteria $(n=1)$ and working without giving up $(n=1)$ helps them to cope with the challenges. In the probing interview about how they cope with an unstable condition T4.S1 reported that "We were in trouble while choosing the best solution. We used the criteria and constraints to choose the best solution."

Students were also asked how they worked as a team in the separate question. Although the students mainly explained they work in a harmony as a team with cooperation and helping with each other $(n=15)$, some of them explained they could not work in a team because of struggling with team members and failing to decide together $(n=6)$ in parallel to the statements in the theme of the challenges. The students' answers indicates that they work in a harmony in their group are as follows. T3.S4 stated that "We were debating, but we worked very well." Similarly, T5.S1 reported that "We worked very well in our team. Only we had a trouble while choosing which structure of the animal we used to design task." According to the teachers' field notes, only in two groups there were serious disputes in team working. Even though six students stated that they could not work as a team only two students wanted to change their group.

The students in the theme of learning in the activity pointed that they learnt about the engineering including how engineers work and nature of engineering $(n=6)$, structure and function in organisms $(n=9)$, working in a team $(n=3)$, scientific inquiry $(n=3)$, building a model/prototype $(n=3)$, knowledge about the living things $(n=1)$, importance of doing research $(n=1)$, decision making $(n=1)$, finding imperfection in design $(n=1)$, understanding project $(n=1)$ and entrepreneurship $(n=1)$. For example, T3.S2 stated that "We used structure and function in order to find a solution for human needs. Engineers use biomimicry as we use." Similarly, T1.S2 stated that "We learned species of living things, engineering and entrepreneurship." The students indicated that their skills to learn science and scientific inquiry in obtaining scientific knowledge developed. For example, T2.S2 reported that "We learned structures of the animals from TUBITAK books. There was a worksheet that we were used for writing what we learn from the book. Using that knowledge, for example Gecko's structure and function we inspired to design not-slip socks." Also, students reported that they learned working in the team. As an example, T2.S1 reported that "We learned how we can make a decision together and working together."

About the themes of likes versus dislikes about the activity the findings indicated that students liked everything in the activity $(n=17)$, the design task and building model/prototype $(n=6)$, learning about animals $(n=5)$, team working $(n=2)$, and brainstorming $(n=2)$. Overall, the students seem to have positive perceptions towards the activity. The collected data by using semi-structured interview supports this finding. For example, one of students (T3.S1) stated that "This activity is both fun and instructive." Another student (T3.S2) pointed that "The idea of the design task was very beautiful. To bring the life the idea made us very happy." Although majority of the students' answers indicated that they like every section in the activity, few of them stated unfavorable sections of the activity including difficulties on some parts of worksheet $(n=1)$, building a design solution $(n=1)$ and drawing of the model/prototype $(n=1)$. Examination of the students' respond in the theme of suggestions for implementation of the activity indicates that the majority of students did not to change anything $(\mathrm{n}=15)$. On the other hand, few students wanted to change such as their team $(\mathrm{n}=2)$, design task $(\mathrm{n}=2)$ and writing task $(\mathrm{n}=1)$. For example, T1.S2 stated that "The design task was very hard. It would be 
better if it would be easier." Another student T2.S2 reported that "I would like to change my team members."

\section{DISCUSSION AND CONCLUSION}

In achieving science goals, students were expected to make observations and conduct investigations to build an understanding of animal behaviors and adaptations. Overall, the students expressed positive science experiences and they were able to identify the structure and its function properly for coherent science learning. In deepening their understanding about nature, the imaginary organism activity it is an effective and fun way to display the relationship between structures and function in organisms for 5th graders. In the similar line, Keçeci, Alan, and Kırbağ Zengin (2017) emphasized the role of inquiry learning to help students integrate STEM disciplines by involving them actively and enjoyable in the science learning process. Another study by Tekerek and Tekerek (2018) supported that instructional materials developed by integrating different disciplines provide an efficient teaching and learning tool.

The results on the biomimicry design task assessment rubric indicate that students can describe how they would adapt the organism's structure to solve the human problem for the engineering design process. But, the students' scores on the first steps of identifying a need or problem including determining criteria and constraints and what they need to know about scientific knowledge to realize their design task are lower than other steps of the engineering design process. Likewise, Karakaya, Yantır1, Y1lmaz, and Y1lmaz (2019) in their study with primary students emphasized shortage of time, materials and information as the problems in the realization of STEM activities. Students' struggles while identifying constraints and criteria were also realized on written documents such that they mixed them and used interchangeably.

The qualitative data obtained from students' responses to reflective open-ended questions and transcribed interviews also confirm these findings such that level of students' literacy about structure and function, perception of the engineering and understanding engineering design process were improved. Related with the engineering design process they gained mainly an ability to build a model/prototype. These outcomes are consistent with many studies in attempt to further development of students engineering design process skills and understanding engineering throughout STEM implications (Baran, Canbazoğlu-Bilici, \& Mesutoğlu, 2015; Duban, Aydoğdu, \& Kolsuz, 2018; Ergün \& Külekçi, 2019; Özcan \& Koca, 2019). Even more striking result is that students can manage to incorporate biomimicry into their design solutions by the way of the complementary relationship between structure and function in organisms. Structure-function model to translate biomimicry into bio-inspired design solutions has been pointed in growing large body of the design based educational literature (Cohen, Reich, \& Greenberg, 2014; Hmelo et al., 2000; Stevens, De Vries, Bos, \& Kopnina, 2019).

As a result of the examining the further findings on the qualitative data we can conclude that they had challenges most with working in a team due to the conflicts and building model/prototype for engineering design process. The challenges may stem from background of the students. It can be seen that it is inevitable for students to face these difficulties because they may have experienced STEM activity and teamwork for the first time in their educational lives. Examining the related literature in the similar context usually support this finding. For example, Özcan and Koca (2019) stated the problems faced with engineering design process as troubles in utilizing the technology, troubles in putting the designs into practice and not respecting the ideas in the group. Similarly, Karakaya et al., (2019) reported as the most revealed problem by the students as the designing and implementing.

The current study also revealed that even the students' answers pointed that working in a team was challenging, they coped with these challenges by working in a harmony as a team. Another supporting idea is that only two students wanted to change their teams when they were asked what you would like 
to change in this study. It can be interpreted that they were learning in the process how to work effectively with their peers in the team. As it is supposed to be they discussed each design solution regarding pros and cons by considering criteria and constrains. This gave them an opportunity to see weakness versus strengths of their design solutions. This finding is consistent with the previous STEM studies in which collaboration has been emerged as prominent $21^{\text {st }}$ century skills that students acquired through the design process (Bolatlı \& Korucu, 2018; Karakaya et al., 2019; Özcan \& Koca, 2019; Özçelik \& Akgündüz, 2018).

Based on the overall findings of the study, it can be concluded that the biomimicry STEM activity provides student actively involved in science and engineering practices. Students were defined the problem, collected data about living things by reading scientific books or watching documentaries or observing living things, collected and interpreted data, developed models, explained their design solutions by using scientific knowledge, and communicating ideas and their findings with their peers. As a core result of the study, biomimicry STEM activity provided students conceptualize the adaptations of living things based on the relationship between structure and function while experiencing the engineering design process. That's why, biomimicry should be considered precisely in science teaching curriculum in terms of providing an opportunity to integrate interdisciplinary STEM into the classroom environment (Gardner, 2012; Pauls, 2017; Yakışan \& Velioğlu, 2019; Yildırım, 2019).

Taking consideration advantage of the features of biomimicry in STEM education can provide a unique learning opportunity for students to understand both scientific concepts and engineering design principles. Moreover, using the relationship between structure and function is an effective way to understand biomimicry and engage students as a bioengineer into engineering design process because of the natural connections between natural and designed world. So, much more research should be needed to explore biomimicry strategies to inspire students in solving human made problems for more sustainable future.

\section{Acknowledgement}

This study includes a part of the second author's PhD Thesis.

Parts of this study were presented at 13th Conference of the European Science Education Research Association (ESERA), Bologna, Italy.

Ethical Approval: For the research, the necessary permission was obtained according to board decision, dated 05/02/2019 and 2439445 numbered from the Research Evaluation and Investigation Committee of the Antalya National Education Directorate. Written informed parental consent form was obtained for all students.

\section{REFERENCES}

Aşık, G, Doğança Küçük, Z., Helvacı, B. \& Çorlu, M. S. (2017). Integrated teaching project: A sustainable approach to teacher education. Turkish Journal of Education, 6(4), 200-215. DOI: 10.19128/turje.332731

Aziz, M. S., \& El sherif, A. Y. (2016). Biomimicry as an approach for bio-inspired structure with the aid of computation. Alexandria Engineering Journal, 55, 707-714. DOI: 10.1016/j.aej.2015.10.015

Baran, E., Canbazoğlu-Bilici, S., \& Mesutoğlu, C. (2015). Science, technology, engineering, and mathematics (STEM) public service announcement (PSA) development activity. Journal of Inquiry Based Activities, $5(2), 60-69$.

Benyus, J. M. (2002). Biomimicry: Innovation inspired by nature. New York: Harper Collins e-books.

Biomimicry Institute (2010). What is biomimicry? Retrieved from https://biomimicry.org/what-is-biomimicry-3/ 
Bolatl1, Z., \& Korucu, A. T. (2018). Secondary school students' feedback on course processing and collaborative learning with web 2.0 tools-supported STEM activities. Bartin University Journal of Faculty of Education, 7(2), 456-478. DOI: 10.14686/buefad.358488

Bybee, R. W. (2013). The next generation science standards and the life sciences. The Science Teacher, 80(2), 25-32.

Cohen, Y. H., Reich, Y., \& Greenberg, S. (2014). Biomimetics: Structure-function patterns approach. Journal of Mechanical Design, 136(11), 111108-1-111108-11.

Corlu, M. S., Capraro, R. M. \& Capraro, M. M. (2014). Introducing STEM education: Implications for educating our teachers for the age of innovation. Education and Science, 39(171), 74-85.

Creswell, J. W. (2014). Research design: Qualitative, quantitative, and mixed methods approaches $\left(4^{\text {th }} \mathrm{ed}\right)$. Thousand Oaks, CA: Sage.

Duban, N., Aydoğdu, B., \& Kolsuz, S. (2018). STEAM implementations for elementary school students in Turkey. Journal of STEM Arts, Crafts, and Constructions, 3(2), 41-58.

Duschl, R. A. (2012). The second dimension-crosscutting concepts. Retrieved from http://static.nsta.org/ngss/resources/201202_Framework-Duschl.pdf

Ergün, A., \& Külekçi, E. (2019). The effect of problem-based STEM education on the perception of 5th grade students of engineering, engineers and technology. Pedagogical Research, 4(3). DOI: 10.29333/pr/5842

Gardner, G. E. (2012). Using biomimicry to engage students in a design-based learning activity. The American Biology Teacher, 74(3), 182-184.

Guzey, S.S., Tank, K., Wang, H., Roehrig, G., \& Moore, T. (2014). A high-quality professional development for teachers of grades 3-6 for implementing engineering into classrooms. School Science and Mathematics, 114(3), 139-149. DOI: $10.1111 / \mathrm{ssm} .12061$

Hmelo, C. E., Holton, D. L., \& Kolodner, J. L. (2000). Designing to learn about complex systems. Journal of the Learning Sciences, 9(3), 247-298. DOI: 10.1207/S15327809JLS0903

Hmelo-Silver, C. E., Marathe, S., \& Liu, L. (2007). Fish swim, rocks sit, and lungs breathe: Expert-novice understanding of complex systems. Journal of the Learning Sciences, 16(3), 307-331. DOI: $10.1080 / 10508400701413401$

Hmelo-Silver, C. E., Jordan, R., Liu, L., Gray, S., Demeter, M., Rugaber, S., \& Goel, A. (2008). Focusing on function: Thinking below the surface of complex natural systems. Science Scope, 31(9), 27-35.

Hwang, J., Jeong, Y., Park, J.M., Lee, K. H., Hong, J. W., \& Choi, J. (2015). Biomimetics: Forecasting the future of science, engineering, and medicine. International Journal of Nanomedicine, 10, 5701-5713.

Karakaya, F., Yantırı, H., Yılmaz, G., \& Yılmaz M. (2019). Determination of primary school students' views about STEM activities: Example of 4th grade. International Journal of Turkish Education Sciences, 7(13), 1-14.

Keçeci, G., Alan, B., \& Kırbağ Zengin, F. (2017). STEM education practices with 5th grade students [Special issue]. Ahi Evran University Journal of Kırşehir Educational Faculty, 18, 1-17.

Kohn, K.P., Underwood, S. M., \& Cooper, M. M. (2018). Connecting structure-property and structure-function relationships across the disciplines of chemistry and biology: Exploring student perceptions. CBE-Life Sciences Education, 17(2). DOI: 10.1187/cbe.18-01-0004

Lederman, N. G. (2019). Illinois institute of technology college of science/bird activity. Retrieved from https://science.iit.edu/sites/science/files/elements/mse/hstp/pdfs/Scenario-Birdactivity.pdf.

Massachusetts Department of Education. (2006). Massachusetts science and technology/engineering curriculum framework. Retrieved from http://www.doe.mass.edu/frameworks/scitech/1006.doc

Ministry of National Education. (2018). Elementary and middle school (3, 4, 5, 6, 7, and $8^{\text {th }}$ grades) science curriculum. Ankara: Board of Education and Training.

Moore, T.J., Stohlmann, M.S., Wang, H.H., Tank, K.M., Glancy, A.W., \& Roehrig, G.H. (2014). Implementation and integration of engineering in K-12 STEM education. In S. Purzer, J. Strobel, \& M. Cardella (Eds.), Engineering in precollege settings: Research into practice (pp. 35-60). West Lafayette, IN: Purdue Press.

National Research Council. (2012). A framework for K-12 science education: Practices, crosscutting concepts, and core ideas. Washington, DC: National Academies Press.

NGSS Lead States. (2013a). Next generation science standards: For states by states. Washington, DC: The National Academies Press.

NGSS Lead States. (2013b). Next generation science standards: For states by states (Vol:2 Appendixes). Washington, DC: The National Academies Press.

Öner, A. T., Navruz, B., Biçer, A., Peterson, C. A., Capraro, R.M., \& Capraro, M.M. (2014). T-STEM academies' academic performance examination by education service centers: A Longitudinal Study. Turkish Journal of Education, 3(4), 40-51. 
Özcan, H., \& Koca, E. (2019). The impact of teaching the subject "pressure" with STEM approach on the academic achievements of the secondary school $7^{\text {th }}$ grade students and their attitudes towards STEM. Education and Science, 44, 201-227. DOI: 10.15390/EB.2019.7902

Özçelik, A., \& Akgündüz, D. (2018). Evaluation of gifted/talented students' out-of-school STEM education. Trakya University Journal of Education Faculty, 8(2), 334-351. DOI: 10.24315/trkefd.331579

Patton, M. Q. (2014). Qualitative evaluation and research methods: Integrating theory and practice. Sage Publications.

Pauls, S. (2017). Biomimicry a "natural lesson" in STEAM. The STEAM Journal, 3(1). DOI: 10.5642/steam.20170301.33

Pauw, I., Kandachar, P., Karana,E., Peck, D., \& Wever, R. (2010, October 25-29). Nature inspired design: Strategies towards sustainability. Paper presented at Knowledge Collaboration \& Learning for Sustainable Innovation: The European Roundtable on Sustainable Consumption and Production (ERSCP) /Environmental Management for Sustainable Universities (EMSU) Conference, Rotterdam, Delft, The Netherlands.

Stevens, L., De Vries, M.J., Bos, M.J.W., \& Kopnina, H. (2019). Biomimicry design education essentials. In W. Sandro, S. Benjamin, \& Gon (Eds.), Proceedings of the $22^{\text {nd }}$ International Conference on Engineering Design (ICED19). (pp. 459-468). Delft, The Netherlands, 5-8 August. DOI:10.1017/dsi.2019.49

Tekerek, M., \& Tekerek, B. (2018). Integrated instructional material and development process. Turkish Journal of Education, 7(3), 156-168. DOI:10.19128/turje.362491.

Wendell, K., Connolly, K., Wright, C., Jarvin, L., Rogers, C., Barnett, M., \& Marulcu, I. (2010, October). Incorporating engineering design into elementary school science curricula. Paper presented at the Annual Meeting of American Society for Engineering Education, Singapore.

Yakışan, M., \& Velioğlu, D. (2019). The analysis of the drawings of the $4^{\text {th }}$ grade students towards biomimicry perceptions. Gazi University Journal of Gazi Educational Faculty (GUJGEF), 39(2), 727- 753. DOI: 10.17152/gefad.547807

Yıldırım, B. (2019). The opinions of pre-service science teachers about biomimicry practices in STEM education. Gazi University Journal of Gazi Educational Faculty (GUJGEF), 39(1), 63-90.

Yildirim, A., \& Simsek, H. (2006). Qualitative research methods in social sciences $\left(5^{\text {th }}\right.$ ed.). Ankara: Seçkin Publications. 


\section{APPENDIX 1}

\section{Biomimicry Design Task}

Nature has been an inspiration for art, design, and innovation for a long time. For example, the wing structure of birds was a guide for humankind who had dreamt of flight and led Wright brothers to invent the plane. The science that brings solutions to problems by mimicking the models and systems in nature or different characteristics of living things is called Biomimicry. Today, applications of biomimicry are used in various fields such as science, technology, art, architecture, artificial intelligence, nanotechnology, robotics, industry, military research, and transportation. A biomimicry company is looking for solutions to human problems by using the characteristics of living things. Company officials in need of new ideas in this field are organizing a competition. As a biomimicry expert, you are expected to solve one of humanity problems by mimicking how plants and animals use their internal and external structures to grow, survive, and meet all their other needs.

To this end, you and your team are expected to observe the structures of living things, collect information about the functions of these structures, and then develop a design to solve a human problem using the complementary relationship between structure and function in organisms. Once you have completed your design, you will present your work to a board of scientists and engineers. In your presentation, you will explain how you created your design by describing the structure of the living thing you have determined and the function of this structure, and how you used these to solve humanity's problems. The specifications of the competition are given below:

\section{Specifications of the competition}

1) Your design must be created by mimicking at least one structure belonging to the organism.

2) Your design must address at least one of human problems.

3) No harmful substances should be used in your design.

4) You can use all kinds of materials in your design, especially recycled materials.

**Through direct observation, watching documentaries or reading scientific books such as publications by TUBITAK, you will determine which organism you will use in your design, the structures belonging to the organism and how they use these structures to survive based on evidence. You can also use other resources (webpages, available printed resources).

You will use the following engineering cycle while performing your design task;

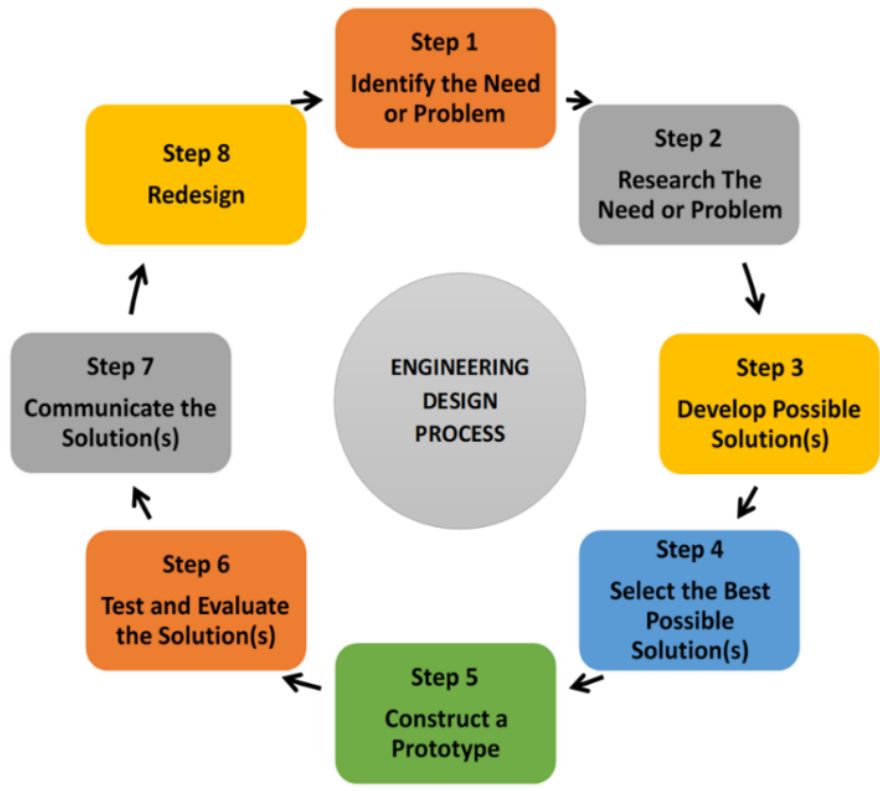




\section{APPENDIX 2}

\section{Structure and Function Worksheet}

Name-Surname:

Summarize the structures that help the survival of organisms you have found in your research and their functions in the table below.

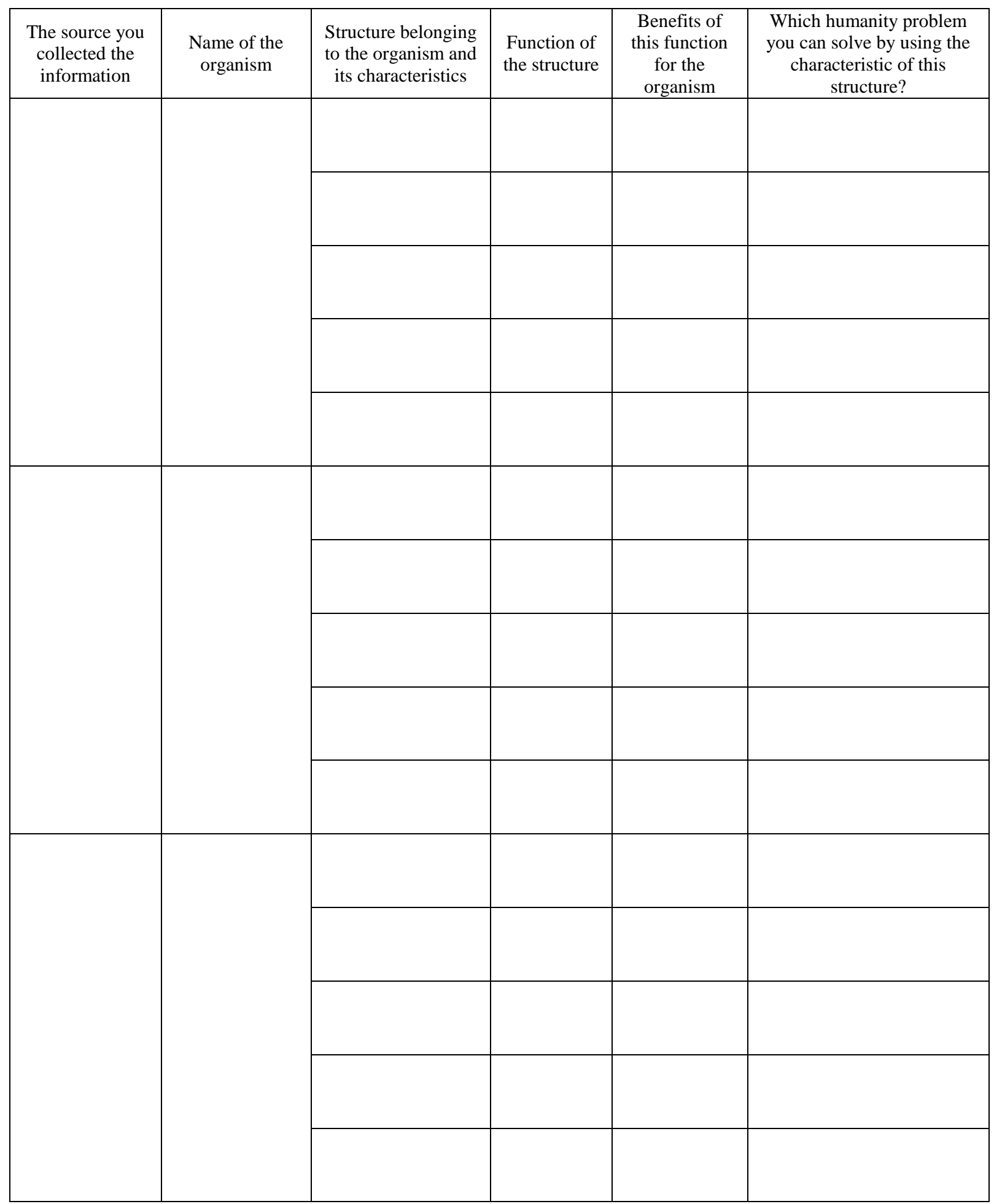




\section{APPENDIX 3}

\section{Imaginary Organism's Adaptations}

Name of your Team:

Think of an imaginary organism with your teammates. You can use the structures and functions of different organisms each of you learned in the first stage while deciding the characteristics of the imaginary organism. Explain the structures you have chosen for your imaginary organism, the functions of these structures and their benefits to the organism using the table below.

\begin{tabular}{|l|l|l|l|}
\hline \multicolumn{1}{|c|}{ Explanations } & $\begin{array}{c}\text { Name and } \\
\text { characteristic of the } \\
\text { structure (wing, tail, } \\
\text { mouth, teeth, root, leaf, } \\
\text { trunk, eye, etc.) }\end{array}$ & $\begin{array}{c}\text { Function of the } \\
\text { structure }\end{array}$ & $\begin{array}{c}\text { Explain why you chose this } \\
\text { structure (What kind of } \\
\text { benefit this structure } \\
\text { provides for the survival of } \\
\text { your organism?) }\end{array}$ \\
\hline $\begin{array}{l}\text { What external structures will } \\
\text { your imaginary organism have? }\end{array}$ & & \\
\hline $\begin{array}{l}\text { What internal structures will } \\
\text { your imaginary organism have? }\end{array}$ & & \\
\hline $\begin{array}{l}\text { What structures will your } \\
\text { imaginary organism have to } \\
\text { find and eat its food? }\end{array}$ & & \\
\hline $\begin{array}{l}\text { What structures will your } \\
\text { imaginary organism have to } \\
\text { protect itself from its enemies? }\end{array}$ & & & \\
\hline $\begin{array}{l}\text { What structures will your } \\
\text { imaginary organism will have } \\
\text { to find a mate? }\end{array}$ & & \\
\hline $\begin{array}{l}\text { What structures will your } \\
\text { imaginary organism have to } \\
\text { communicate with its friends } \\
\text { and offspring? }\end{array}$ & & & \\
\hline & & & \\
\hline
\end{tabular}




\section{APPENDIX 4}

\section{Drawing and Labeling the Imaginary Organism}

Name of your Team:

Draw the picture of your organism you have imagined. While drawing your picture, be sure to label the structures of the organism you have imagined in detail.

Scientific name of your imaginary organism:

Write a story or news that introduces your imaginary organism to the world of science: 


\section{APPENDIX 5}

\section{Introducing Imaginary Organism}

Name of your Team:

You will introduce your imaginary organism to the world of science. To do this, you will form the following species tag. In this tag, you can mention the structures and characteristics of your organism, the group its scientifically belong, habitat, nest, food sources, enemies, etc.

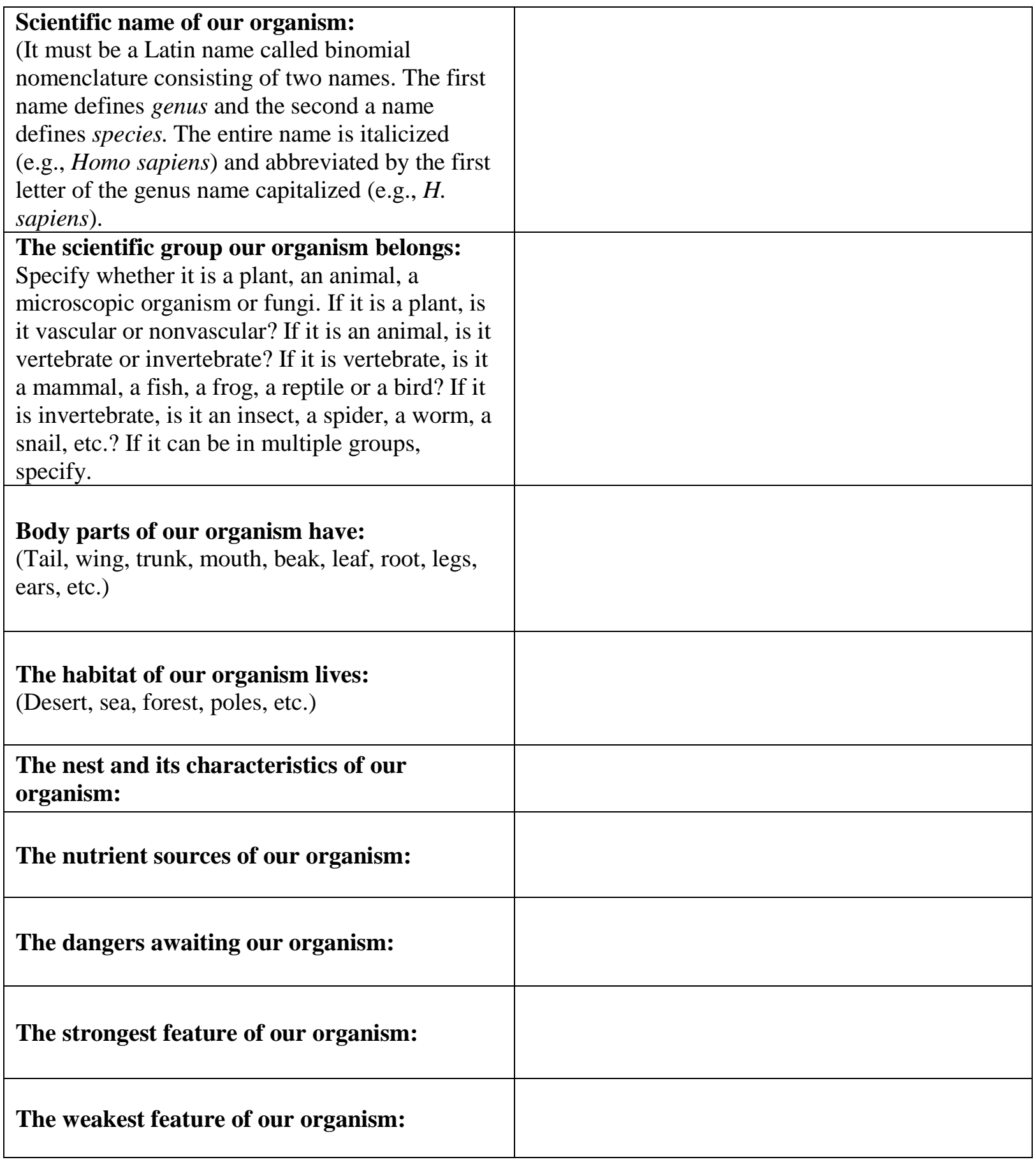




\section{APPENDIX 6}

\section{Imaginary Organism Assessment Rubric}

Name of Team:

\begin{tabular}{|c|c|c|c|c|c|}
\hline \multirow{2}{*}{ Dimension } & \multirow{2}{*}{ Criteria } & \multicolumn{4}{|c|}{ Imaginary Organism Assessment Rubric } \\
\hline & & 0 & 1 & 2 & 3 \\
\hline \multirow{3}{*}{$\begin{array}{l}\text { Developing } \\
\text { and using } \\
\text { models }\end{array}$} & $\begin{array}{l}\text { Name and } \\
\text { classification of } \\
\text { organism }\end{array}$ & $\begin{array}{l}\text { No evidence } \\
\text { of the name or } \\
\text { classification } \\
\text { of the } \\
\text { organism }\end{array}$ & $\begin{array}{l}\text { The organism is } \\
\text { named but not } \\
\text { classified. }\end{array}$ & $\begin{array}{l}\text { The organism is } \\
\text { classified but } \\
\text { not named. }\end{array}$ & $\begin{array}{l}\text { The organism is } \\
\text { named and } \\
\text { classified }\end{array}$ \\
\hline & $\begin{array}{l}\text { Drawing and } \\
\text { labeling }\end{array}$ & $\begin{array}{l}\text { No evidence } \\
\text { of drawing of } \\
\text { the organism }\end{array}$ & $\begin{array}{l}\text { Drawing of the } \\
\text { organism is } \\
\text { unclear and lack } \\
\text { of finer details. }\end{array}$ & $\begin{array}{l}\text { Drawing of the } \\
\text { organism is } \\
\text { clear but lack of } \\
\text { finer details. }\end{array}$ & $\begin{array}{l}\text { Drawing of the } \\
\text { organism is } \\
\text { clear and has } \\
\text { finer details. }\end{array}$ \\
\hline & Description & $\begin{array}{l}\text { No evidence } \\
\text { of description } \\
\text { of the } \\
\text { organism }\end{array}$ & $\begin{array}{l}\text { Description of } \\
\text { the organism } \\
\text { does not match } \\
\text { the drawing. }\end{array}$ & $\begin{array}{l}\text { Description of } \\
\text { the organism } \\
\text { does not exactly } \\
\text { match the } \\
\text { drawing. }\end{array}$ & $\begin{array}{l}\text { Description of } \\
\text { the organism } \\
\text { matches the } \\
\text { drawing. }\end{array}$ \\
\hline \multirow{5}{*}{$\begin{array}{l}\text { Structure } \\
\text { and } \\
\text { function }\end{array}$} & Nutrition & $\begin{array}{l}\text { No evidence } \\
\text { of relation } \\
\text { between } \\
\text { structure and } \\
\text { function }\end{array}$ & $\begin{array}{l}\text { The organism } \\
\text { cannot consume } \\
\text { nutrients with } \\
\text { its modelled } \\
\text { structures. }\end{array}$ & $\begin{array}{l}\text { The organism } \\
\text { hardly } \\
\text { consumes } \\
\text { nutrients with } \\
\text { its modelled } \\
\text { structures. }\end{array}$ & $\begin{array}{l}\text { The organism } \\
\text { consumes } \\
\text { nutrients easily } \\
\text { with its } \\
\text { modelled } \\
\text { structures. }\end{array}$ \\
\hline & $\begin{array}{l}\text { Defending from } \\
\text { predators }\end{array}$ & $\begin{array}{l}\text { No evidence } \\
\text { of relation } \\
\text { between } \\
\text { structure and } \\
\text { function }\end{array}$ & $\begin{array}{l}\text { The organism } \\
\text { cannot protect } \\
\text { itself from its } \\
\text { predators with } \\
\text { its modelled } \\
\text { structures. }\end{array}$ & $\begin{array}{l}\text { The organism } \\
\text { hardly protects } \\
\text { itself from its } \\
\text { predators with } \\
\text { its modelled } \\
\text { structures. }\end{array}$ & $\begin{array}{l}\text { The organism } \\
\text { can protect } \\
\text { itself easily } \\
\text { from its } \\
\text { predators with } \\
\text { its modelled } \\
\text { structures. }\end{array}$ \\
\hline & Communication & $\begin{array}{l}\text { No evidence } \\
\text { of relation } \\
\text { between } \\
\text { structure and } \\
\text { function }\end{array}$ & $\begin{array}{l}\text { The organism } \\
\text { cannot } \\
\text { communicate } \\
\text { with its } \\
\text { modelled } \\
\text { structures. }\end{array}$ & $\begin{array}{l}\text { The organism } \\
\text { can hardly } \\
\text { communicate } \\
\text { with its } \\
\text { modelled } \\
\text { structures. }\end{array}$ & $\begin{array}{l}\text { The organism } \\
\text { can } \\
\text { communicate } \\
\text { easily with its } \\
\text { modelled } \\
\text { structures. }\end{array}$ \\
\hline & Mating & $\begin{array}{l}\text { No evidence } \\
\text { of relation } \\
\text { between } \\
\text { structure and } \\
\text { function }\end{array}$ & $\begin{array}{l}\text { The organism } \\
\text { cannot find a } \\
\text { mate with its } \\
\text { modelled } \\
\text { structures. }\end{array}$ & $\begin{array}{l}\text { The organism } \\
\text { hardly finds a } \\
\text { mate with its } \\
\text { modelled } \\
\text { structures. }\end{array}$ & $\begin{array}{l}\text { The organism } \\
\text { can find a mate } \\
\text { easily with its } \\
\text { modelled } \\
\text { structures. }\end{array}$ \\
\hline & Habitat & $\begin{array}{l}\text { No evidence } \\
\text { of relation } \\
\text { between } \\
\text { structure and } \\
\text { function }\end{array}$ & $\begin{array}{l}\text { The organism } \\
\text { cannot survive } \\
\text { with its } \\
\text { modelled } \\
\text { structures in its } \\
\text { habitat. }\end{array}$ & $\begin{array}{l}\text { The organism } \\
\text { hardly survives } \\
\text { with its } \\
\text { modelled } \\
\text { structures in its } \\
\text { habitat. }\end{array}$ & $\begin{array}{l}\text { The organism } \\
\text { can survive } \\
\text { easily with its } \\
\text { modelled } \\
\text { structures in its } \\
\text { habitat. }\end{array}$ \\
\hline Total Score & $\ldots / 24$ & & & & \\
\hline
\end{tabular}




\section{APPENDIX 7}

\section{Great Design Task Draft Drawing}

\section{Name of your Team:}

At the beginning of the unit, read the great design task you were given again. You will apply the scientific knowledge you have learned up to this stage on your great designing task. Answer the following questions and draw the sketch of the design you have made with your team below.

While creating your design, which organisms did you use the structure and the function of?

What human problem will your design solve, and how?

Which materials will you use in which part of your design?

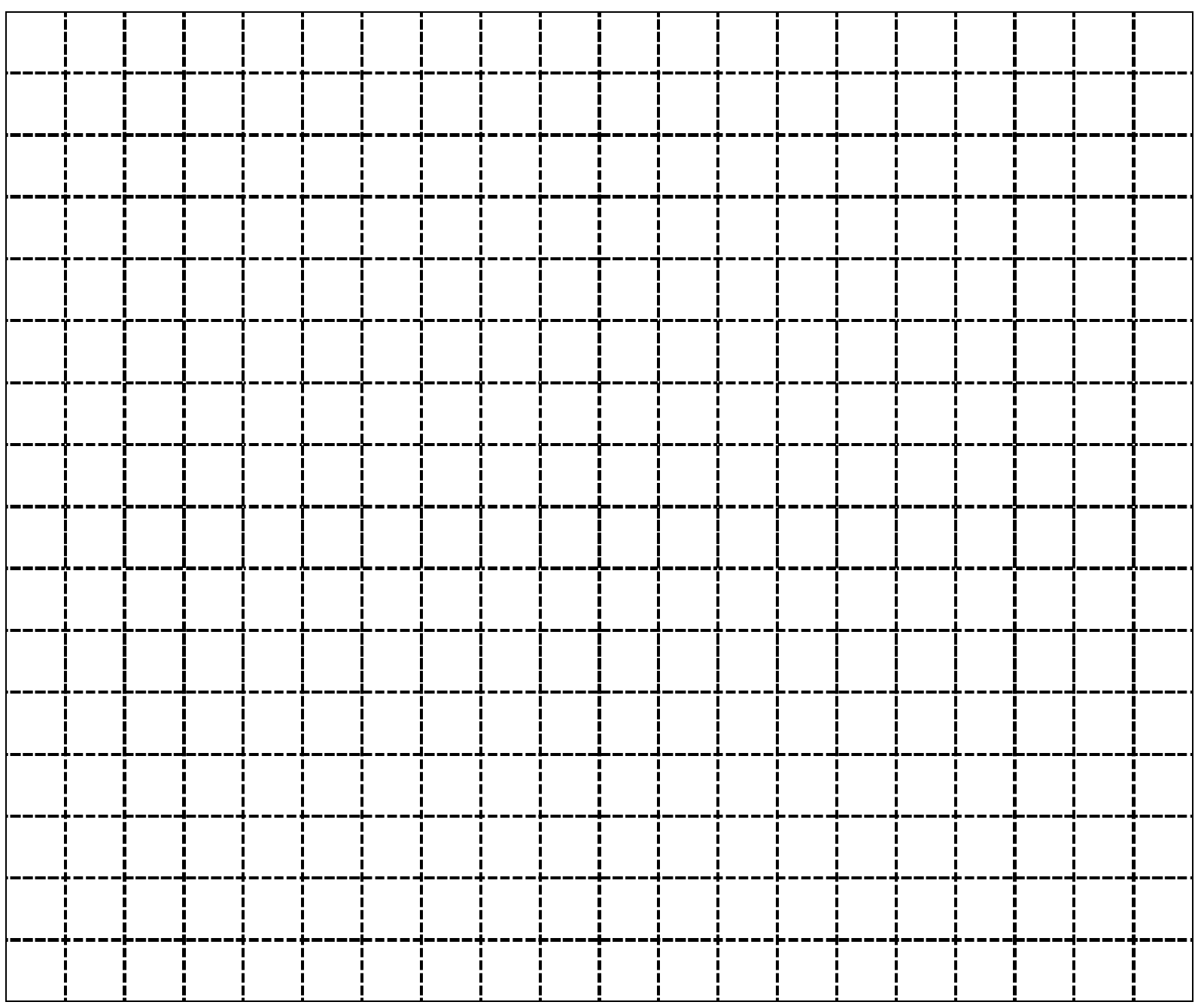




\section{APPENDIX 8}

Biomimicry Design Task Assessment Rubric

\begin{tabular}{|c|c|c|c|c|}
\hline $\begin{array}{c}\text { Engineering } \\
\text { Design Process } \\
\text { Steps }\end{array}$ & 0 & 1 & 2 & 3 \\
\hline \multirow{2}{*}{$\begin{array}{l}\text { Identify the } \\
\text { need/problem }\end{array}$} & $\begin{array}{l}\text { The need/problem was } \\
\text { not identified. }\end{array}$ & $\begin{array}{l}\text { The need/problem was } \\
\text { defined superficially. }\end{array}$ & $\begin{array}{l}\text { The need/problem was } \\
\text { identified. }\end{array}$ & $\begin{array}{l}\text { The need/problem was } \\
\text { identified clearly with all } \\
\text { details. }\end{array}$ \\
\hline & $\begin{array}{l}\text { The criteria and } \\
\text { constraints were not } \\
\text { identified. }\end{array}$ & $\begin{array}{l}\text { Some of the criteria and } \\
\text { constraints were identified. }\end{array}$ & $\begin{array}{l}\text { Most of the criteria and } \\
\text { constraints were } \\
\text { identified. }\end{array}$ & $\begin{array}{l}\text { All the criteria and } \\
\text { constraints were identified. }\end{array}$ \\
\hline \multirow{2}{*}{$\begin{array}{l}\text { Research the } \\
\text { need or the } \\
\text { problem }\end{array}$} & $\begin{array}{l}\text { The information needed } \\
\text { for the solution of the } \\
\text { need/problem was not } \\
\text { determined. }\end{array}$ & $\begin{array}{l}\text { Some of the information } \\
\text { needed for the solution of the } \\
\text { need/problem was defined. }\end{array}$ & $\begin{array}{l}\text { Most of the information } \\
\text { needed for the solution of } \\
\text { the need/problem was } \\
\text { defined. }\end{array}$ & $\begin{array}{l}\text { All the information needed } \\
\text { for the solution of the } \\
\text { need/problem was defined. }\end{array}$ \\
\hline & $\begin{array}{l}\text { It was not defined how } \\
\text { the collected } \\
\text { information would be } \\
\text { used to solve the } \\
\text { need/problem. }\end{array}$ & $\begin{array}{l}\text { It was superficially defined } \\
\text { how the collected } \\
\text { information would be used to } \\
\text { solve the need/problem. }\end{array}$ & $\begin{array}{l}\text { It was defined how the } \\
\text { collected information } \\
\text { would be used to solve } \\
\text { the need/problem. }\end{array}$ & $\begin{array}{l}\text { It was clearly defined in } \\
\text { detail on how the collected } \\
\text { information would be used } \\
\text { to solve the need/problem. }\end{array}$ \\
\hline \multirow{2}{*}{$\begin{array}{l}\text { Develop } \\
\text { possible } \\
\text { solution(s) }\end{array}$} & $\begin{array}{l}\text { No solution was } \\
\text { proposed for the } \\
\text { need/problem. }\end{array}$ & $\begin{array}{l}\text { The proposed solution for } \\
\text { the need/problem was met } \\
\text { the some of the criteria and } \\
\text { constraints. }\end{array}$ & $\begin{array}{l}\text { The proposed solution for } \\
\text { the need/problem was met } \\
\text { most of the criteria and } \\
\text { constraints. }\end{array}$ & $\begin{array}{l}\text { The proposed solution for } \\
\text { the need/problem was met } \\
\text { the all the criteria and } \\
\text { constraints. }\end{array}$ \\
\hline & $\begin{array}{l}\text { No blueprint drawn for } \\
\text { proposed solution. }\end{array}$ & $\begin{array}{l}\text { The blueprint was reflected } \\
\text { the solution proposal } \\
\text { superficially. }\end{array}$ & $\begin{array}{l}\text { The blueprint was } \\
\text { reflected the solution } \\
\text { proposal. }\end{array}$ & $\begin{array}{l}\text { The blueprint was reflected } \\
\text { the solution proposal in } \\
\text { detail. }\end{array}$ \\
\hline \multirow[b]{2}{*}{$\begin{array}{l}\text { Select the best } \\
\text { solution(s) }\end{array}$} & $\begin{array}{l}\text { The pros and cons of } \\
\text { proposed solutions were } \\
\text { not defined. }\end{array}$ & $\begin{array}{l}\text { Some of the pros and cons of } \\
\text { proposed solutions were } \\
\text { defined. }\end{array}$ & $\begin{array}{l}\text { Most of the pros and cons } \\
\text { of proposed solutions } \\
\text { were defined. }\end{array}$ & $\begin{array}{l}\text { All the pros and cons of } \\
\text { proposed solutions were } \\
\text { defined with details. }\end{array}$ \\
\hline & $\begin{array}{l}\text { Whether the chosen } \\
\text { solution meets the } \\
\text { criteria and constraints } \\
\text { were not explained. }\end{array}$ & $\begin{array}{l}\text { Some of the reasons for the } \\
\text { chosen solution were } \\
\text { explained. }\end{array}$ & $\begin{array}{l}\text { Most of the reasons for } \\
\text { the chosen solution were } \\
\text { explained. }\end{array}$ & $\begin{array}{l}\text { All the reasons for the } \\
\text { chosen solution were } \\
\text { explained with details. }\end{array}$ \\
\hline \multirow{2}{*}{$\begin{array}{l}\text { Construct a } \\
\text { prototype }\end{array}$} & $\begin{array}{l}\text { A model/prototype for } \\
\text { the solution proposal } \\
\text { was not created. }\end{array}$ & $\begin{array}{l}\text { A partially appropriate } \\
\text { model/prototype for the } \\
\text { solution proposal was } \\
\text { created. }\end{array}$ & $\begin{array}{l}\text { An appropriate } \\
\text { model/prototype for the } \\
\text { solution proposal was } \\
\text { created. }\end{array}$ & $\begin{array}{l}\text { A completely appropriate } \\
\text { model/prototype for the } \\
\text { solution proposal was } \\
\text { created. }\end{array}$ \\
\hline & $\begin{array}{l}\text { The materials that meet } \\
\text { the criteria and } \\
\text { restrictions for the } \\
\text { model/prototype were } \\
\text { not used. }\end{array}$ & $\begin{array}{l}\text { The materials that meet part } \\
\text { of the criteria and restrictions } \\
\text { for the model/prototype were } \\
\text { used. }\end{array}$ & $\begin{array}{l}\text { The materials that meet } \\
\text { most of the criteria and } \\
\text { restrictions for the } \\
\text { model/prototype were } \\
\text { used. }\end{array}$ & $\begin{array}{l}\text { The materials that meet all } \\
\text { the criteria and restrictions } \\
\text { for the model/prototype } \\
\text { were used. }\end{array}$ \\
\hline \multirow{2}{*}{$\begin{array}{l}\text { Test and } \\
\text { evaluate the } \\
\text { solution(s) }\end{array}$} & $\begin{array}{l}\text { It was not tested how the } \\
\text { model/prototype solves } \\
\text { the need/problem. }\end{array}$ & $\begin{array}{l}\text { The model/prototype was } \\
\text { tested how it would solve the } \\
\text { need / problem. Test results } \\
\text { were not analyzed. }\end{array}$ & $\begin{array}{l}\text { The model/prototype was } \\
\text { tested how it would solve } \\
\text { the need/problem. Part of } \\
\text { the test results were } \\
\text { analyzed }\end{array}$ & $\begin{array}{l}\text { The model/prototype was } \\
\text { tested how it would solve } \\
\text { the need/problem. All the } \\
\text { test results were analyzed } \\
\text { completely. }\end{array}$ \\
\hline & $\begin{array}{l}\text { The data related to the } \\
\text { test results were not } \\
\text { explained by using } \\
\text { scientific language. }\end{array}$ & $\begin{array}{l}\text { Part of the data related to the } \\
\text { test results were partly } \\
\text { explained by using scientific } \\
\text { language. }\end{array}$ & $\begin{array}{l}\text { Most of the data related to } \\
\text { the test results were } \\
\text { explained by using } \\
\text { scientific language. }\end{array}$ & $\begin{array}{l}\text { All the data related to the } \\
\text { test results were explained } \\
\text { by using scientific language } \\
\text { completely with details. }\end{array}$ \\
\hline \multirow[b]{2}{*}{$\begin{array}{l}\text { Communicate } \\
\text { the solution(s) }\end{array}$} & $\begin{array}{l}\text { It was not explained } \\
\text { how the designs would } \\
\text { solve the need/problem. }\end{array}$ & $\begin{array}{l}\text { It was partly explained how } \\
\text { the designs would solve the } \\
\text { need/problem. }\end{array}$ & $\begin{array}{l}\text { It was explained how the } \\
\text { designs would solve the } \\
\text { need/problem. }\end{array}$ & $\begin{array}{l}\text { It was explained completely } \\
\text { how the designs would } \\
\text { solve the need/problem } \\
\text { with details. }\end{array}$ \\
\hline & $\begin{array}{l}\text { The structure/structures } \\
\text { belonging to living } \\
\text { things and how the } \\
\text { functions of these } \\
\text { structures are utilized } \\
\text { were not identified. }\end{array}$ & $\begin{array}{l}\text { The structure/structures } \\
\text { belonging to living things } \\
\text { and how the functions of } \\
\text { these structures are utilized } \\
\text { were partly identified. }\end{array}$ & $\begin{array}{l}\text { The structure /structures } \\
\text { belonging to living things } \\
\text { and how the functions of } \\
\text { these structures are } \\
\text { utilized were identified. }\end{array}$ & $\begin{array}{l}\text { The structure /structures } \\
\text { belonging to living things } \\
\text { and how the functions of } \\
\text { these structures are utilized } \\
\text { were completely identified } \\
\text { with details. }\end{array}$ \\
\hline \multirow[b]{2}{*}{ Redesign } & $\begin{array}{l}\text { The need of } \\
\text { improvement for designs } \\
\text { was not identified. }\end{array}$ & $\begin{array}{l}\text { The need of improvement for } \\
\text { design was partly identified. }\end{array}$ & $\begin{array}{l}\text { The need of improvement } \\
\text { for design was identified. }\end{array}$ & $\begin{array}{l}\text { The need of improvement } \\
\text { for design was identified } \\
\text { with details. }\end{array}$ \\
\hline & $\begin{array}{l}\text { The design was not } \\
\text { improved in the light of } \\
\text { the data and feedbacks } \\
\text { from the test results and } \\
\text { the communication of } \\
\text { the solutions. }\end{array}$ & $\begin{array}{l}\text { The design was partly } \\
\text { improved in the light of the } \\
\text { data and feedbacks from the } \\
\text { test results and the } \\
\text { communication of the } \\
\text { solutions. }\end{array}$ & $\begin{array}{l}\text { The design was improved } \\
\text { in the light of the data and } \\
\text { feedbacks from the test } \\
\text { results and the } \\
\text { communication of the } \\
\text { solutions. }\end{array}$ & $\begin{array}{l}\text { The design was optimally } \\
\text { improved in the light of the } \\
\text { data and feedbacks from the } \\
\text { test results and the } \\
\text { communication of the } \\
\text { solutions. }\end{array}$ \\
\hline Total Score & $\ldots / 48$ & & & \\
\hline
\end{tabular}




\section{APPENDIX 9}

\section{Biomimicry STEM Activity Reflective Evaluation Form}

Write your answers to the following questions in the gaps. You can add drawings to explain. You can use the backside of the paper or a separate paper for your drawings.

1. What kind of difficulties did you face when designing your model / prototype?

2. How did you overcome these difficulties?

3. What did you learn in this activity?

4. What did you do to improve your model/prototype?

5. What did you like in this activity?

6. What did you dislike in this activity?

7. Explain how did you work as a team?

8. What would you like to change in this activity? 


\section{APPENDIX 10}

\section{Drawings and Created Imaginary Organisms}

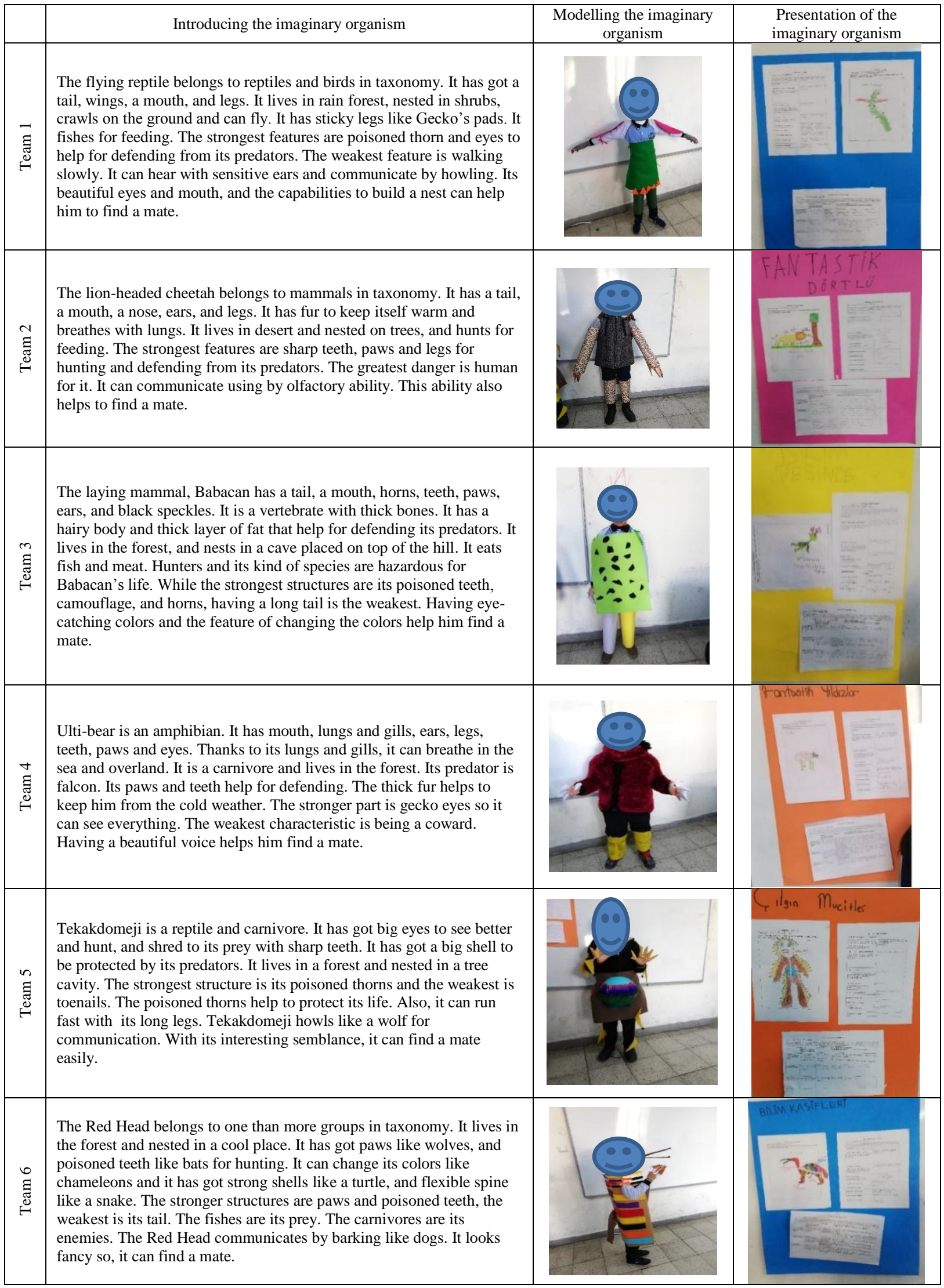




\section{APPENDIX 11}

\section{Sample Drawings of Great Design}

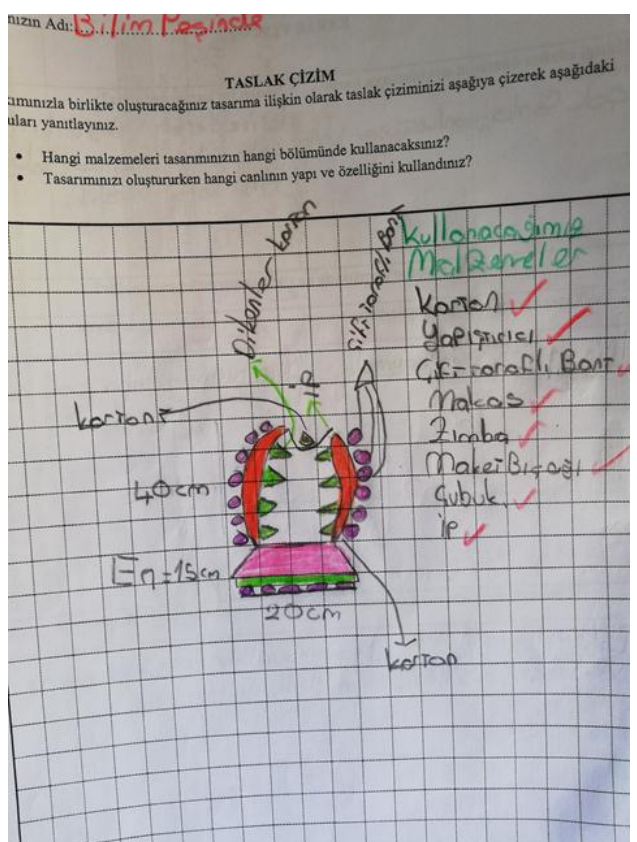

Team 3

Blueprint of the Trap

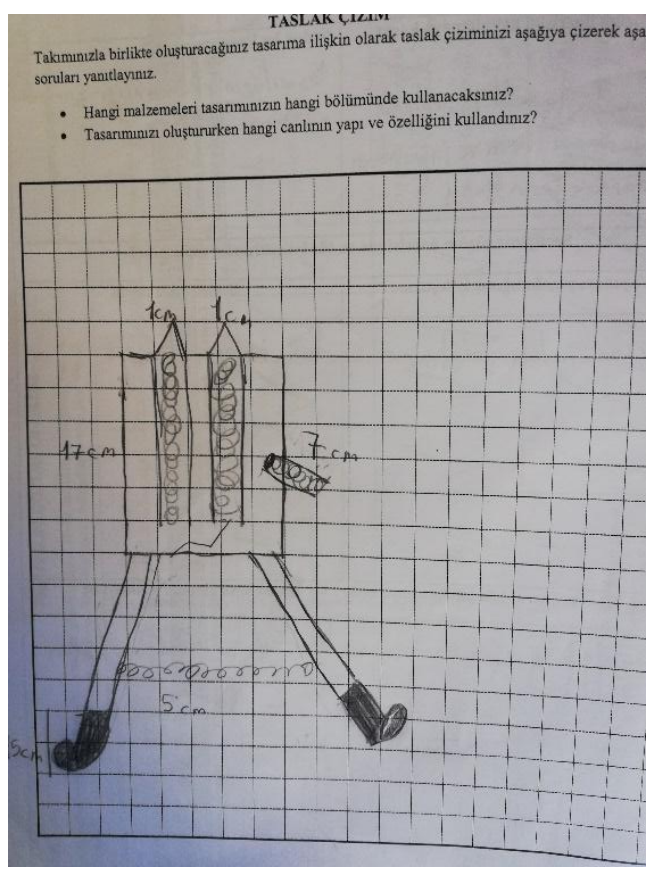

Team 5

Blueprint of the Sew-burry

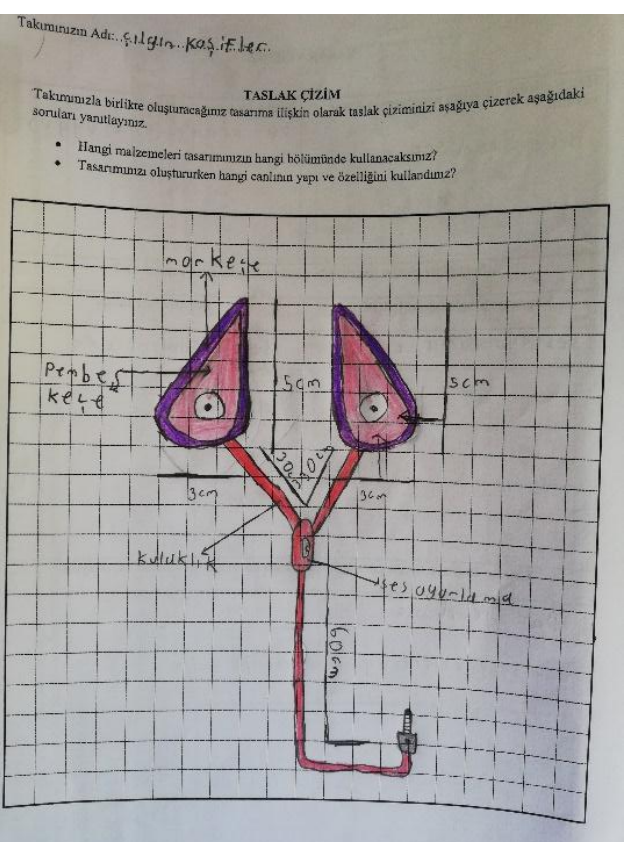

Team 4

Blueprint of the Bat's Ear Headset

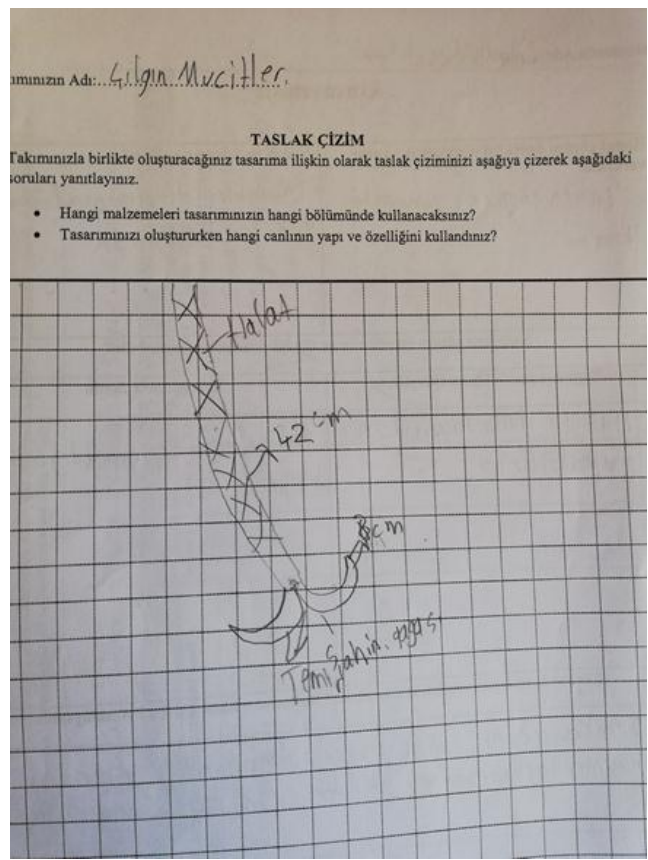

Team 5

Blueprint of the Hook 


\section{APPENDIX 12}

\section{Developed Biomimicry Models}

\begin{tabular}{|c|c|c|c|c|c|c|c|}
\hline Team & The model & $\begin{array}{l}\text { The name } \\
\text { of the } \\
\text { organism } \\
\text { used in } \\
\text { the design }\end{array}$ & $\begin{array}{l}\text { Structure } \\
\text { of the } \\
\text { organism }\end{array}$ & $\begin{array}{l}\text { Function of } \\
\text { the structure }\end{array}$ & $\begin{array}{l}\text { What kind } \\
\text { of human } \\
\text { problems } \\
\text { solved by } \\
\text { your } \\
\text { design? }\end{array}$ & $\begin{array}{l}\text { How it } \\
\text { works? }\end{array}$ & $\begin{array}{l}\text { What } \\
\text { improvement } \\
\text { needs in your } \\
\text { design? }\end{array}$ \\
\hline $\begin{array}{l}\text { Team } 1 \\
\text { Fishing- } \\
\text { net }\end{array}$ & $\int^{x}$ & Pelican & Beak & $\begin{array}{l}\text { Scooping - } \\
\text { up fish with } \\
\text { its large } \\
\text { shape. }\end{array}$ & $\begin{array}{c}\text { To help } \\
\text { people fish. }\end{array}$ & $\begin{array}{l}\text { Water } \\
\text { drains from } \\
\text { the holes } \\
\text { and fishes } \\
\text { remain in } \\
\text { the net. }\end{array}$ & $\begin{array}{c}\text { The drainage } \\
\text { holes for water } \\
\text { were too small. } \\
\text { It needs to be } \\
\text { larger. }\end{array}$ \\
\hline $\begin{array}{l}\text { Team } 2 \\
\text { Non- } \\
\text { slip } \\
\text { socks }\end{array}$ & & Gecko & Toe-pads & $\begin{array}{c}\text { Climbing } \\
\text { on surfaces } \\
\text { without } \\
\text { slipping or } \\
\text { falling } \\
\text { down. }\end{array}$ & $\begin{array}{l}\text { To prevent } \\
\text { people from } \\
\text { slipping } \\
\text { and falling. }\end{array}$ & $\begin{array}{l}\text { Sipped } \\
\text { silicone } \\
\text { prevents } \\
\text { slipping. }\end{array}$ & $\begin{array}{c}\text { The slip-proof } \\
\text { material under } \\
\text { the stocking } \\
\text { was thick. It } \\
\text { needs to be } \\
\text { thinner. }\end{array}$ \\
\hline $\begin{array}{c}\text { Team } 3 \\
\text { Trap }\end{array}$ & & $\begin{array}{l}\text { Venus } \\
\text { Flytrap }\end{array}$ & Leaves & $\begin{array}{l}\text { Catching } \\
\text { the bugs } \\
\text { and flies }\end{array}$ & $\begin{array}{c}\text { To help } \\
\text { people hunt }\end{array}$ & $\begin{array}{l}\text { When the } \\
\text { animal steps } \\
\text { on the trap, } \\
\text { two leaves } \\
\text { are closed. }\end{array}$ & $\begin{array}{l}\text { Need to expand } \\
\text { the rim of } \\
\text { model }\end{array}$ \\
\hline $\begin{array}{l}\text { Team } 4 \\
\text { Bat's } \\
\text { Ear } \\
\text { Headset }\end{array}$ & & Bat & Ears & $\begin{array}{c}\text { Seeing with } \\
\text { ears }\end{array}$ & $\begin{array}{l}\text { To enable } \\
\text { deaf } \\
\text { people, } \\
\text { hear and for } \\
\text { sound } \\
\text { insulation. }\end{array}$ & $\begin{array}{l}\text { It sends } \\
\text { sound } \\
\text { waves to } \\
\text { human } \\
\text { brain. }\end{array}$ & $\begin{array}{c}\text { Size of the } \\
\text { headset }\end{array}$ \\
\hline $\begin{array}{l}\text { Team } 5 \\
\text { Hook }\end{array}$ & & Falcon & Claws & $\begin{array}{l}\text { Hunting } \\
\text { their prey } \\
\text { and carry } \\
\text { out. }\end{array}$ & $\begin{array}{l}\text { To help } \\
\text { people } \\
\text { carry heavy } \\
\text { things }\end{array}$ & $\begin{array}{l}\text { The load } \\
\text { can be hung } \\
\text { on the hook } \\
\text { and people } \\
\text { hold in } \\
\text { high. }\end{array}$ & \\
\hline $\begin{array}{l}\text { Team } 6 \\
\text { Sew- } \\
\text { burry }\end{array}$ & 84 & Chicken & Beak & $\begin{array}{l}\text { Fighting } \\
\text { and } \\
\text { protecting, } \\
\text { Breaking } \\
\text { grass and } \\
\text { digging the } \\
\text { soil. }\end{array}$ & $\begin{array}{l}\text { To help } \\
\text { people } \\
\text { plant seed } \\
\text { easily }\end{array}$ & $\begin{array}{l}\text { The one of } \\
\text { chicken's } \\
\text { beak digs } \\
\text { the hole and } \\
\text { another puts } \\
\text { the seed and } \\
\text { closes the } \\
\text { hole. }\end{array}$ & $\begin{array}{l}\text { In our model } \\
\text { the beak did } \\
\text { not looks like a } \\
\text { chicken beak. }\end{array}$ \\
\hline
\end{tabular}




\section{TÜRKÇE GENIŞLETILMIŞ ÖZET}

Doğa bilimlerini anlamada en önemli mihenk taşlarından biri 'yapı fonksiyonu belirler' temasıdır. Ulusal Araştırma Konseyi (National Research Council [NRC], 2012) tarafından geliştirilen K-12 Fen Eğitimi Çerçevesi: Uygulamalar, Kesişen Kavramlar ve Öz Fikirler reform belgesinde, yapı ve işlev arasındaki ilişki bilim ve mühendislik uygulamaları yoluyla hem kesişen hem de disiplin temel kavramları olarak kabul edilmektedir. Tüm disiplinlerde ve sınıf seviyelerinde temaları birleştiren kesişen kavramlar arasında yer alan yapı ve işlev "bir nesnenin ya da canlının oluşma biçimi ve alt bileşenleri, özelliklerini ve fonksiyonunu belirler" şeklinde tanımlanmaktadır (NRC, 2012, s. 84). Bu çerçevede fizik ve yaşam bilimlerindeki disiplin temel fikirlerinin ana bileşenleri olarak ise yapı ve işlev, sırasıyla 'Maddenin yapısı ve özellikleri' ve 'Yapı ve işlev' içeriğinde yer almaktadır. Diğer taraftan ülkemizde yakın zamanda revize edilen fen programında ise öğrencilerin feni diğer disiplinlerle bütünleştirerek teoriyi pratiğe ve ürüne dönüştürebilmelerine yardımcı olacak fen ve mühendislik uygulamalarına vurgu yapılırken; doğada ya da tasarlanmış dünyada tekrar eden örüntülere ve yapı ve işlev arasındaki ilişkilere herhangi bir sınıf düzeyinde vurgu yapılmamıştır.

Doğa uzun zamandır sanat, tasarım ve yenilik için bir ilham kaynağı olmuştur. Örneğin, uçma hayali kuran insanoğluna kuşların kanat yapıları en büyük yol gösterici olmuş ve bu sayede Wright kardeşler uçağı icat etmişlerdir. Benyus'a (2002) göre milyarlarca yıllık evrimsel süreç, organizmalara canlılıklarını sürdürebilmeleri için inanılmaz çeşitlilikte yapılar, şekiller ve bunlarla ilgili işlevler kazandırmıştır. Bu nedenle, yapı ve fonksiyon arasındaki ilişkiyi anlamak mühendislik tasarımları ve özellikle de biyomimikri tasarımları için kritik bir öneme sahiptir (Cohen, Reich ve Greenberg, 2014). Biyomimikri "doğanın zaman içinde test edilmiş kalıplarını ve stratejilerini taklit ederek insanların sorunlarına sürdürülebilir çözümler arayan yenilikçi bir yaklaşımdır” (Biomimicry Institute, 2010).

Öğrencilerin doğal dünyadaki organizmaları sorgulayarak yapıların işlevlerini ne ölçüde anladıklarıyla ilgili olarak nedensel çıkarımlar yapmaları gerekir. Bu, "mühendislerin doğadaki yapıları insanların ihtiyaçlarını karşılayacak tasarımlar için ilham kaynağı olarak incelerken böyle çıkarımlar yapmalarına" benzer bir yöntemdir (Yeni Nesil Fen Standartları [NGSS] Lead States, 2013b, s.89). Mühendisler doğayı inceleyerek öğrenirler. Bu yüzden yeni tasarım çözümleri için daha mükemmel fikirler elde etmek için doğayı gözlemlerler. Bu durum, günlük yaşamımızda kullandığımız birçok teknolojik aracın neden doğadaki bir mekanizma ile aynı şekilde çalıştığını açıklar. "Doğal ve insan yapımı sistemlerin benzer şekilde işleyişinin, bazı kilit parçaların şekillerine ve ilişkilerine bağlı olduğu kadar üretildikleri malzemelerin özelliklerine de bağlı olduğu" görülebilir (NRC, 2012, s.96). $\mathrm{Bu}$ nedenle, doğadaki yapıların amacının veya mekanik fonksiyonunun fen bilgisi derslerinde bir öğrenme çıktısı olarak anlaşılması STEM eğitiminde önemsenmelidir.

STEM eğitiminde biyomimikrinin özelliklerinden yararlanmak, öğrencilere hem bilimsel kavramları hem de mühendislik tasarım ilkelerini anlamalarında eşsiz bir öğrenme firsatı sunmaktadır. Yapı ve fonksiyon arasındaki ilişkiyi kullanarak biyomimikriyi anlamak, doğal ve insanoğlu tarafından inşaa edilen dünya arasındaki bağlantılar nedeniyle öğrencileri bir biyomühendis olarak mühendislik tasarımına dahil etmenin etkili bir yoludur. Bu çalışma, beşinci sınıf fen bilimleri dersi Canlılar Dünyası ünitesinde yapı ve fonksiyon ilişkisine dayanan biyomimikri STEM etkinliği geliştirmeyi amaçlamaktadır. Çalışmada durum çalışması yöntemi kullanılmış, sosyo ekenomik düzeyi düşük bir devlet ortaokulunda 12 ders boyunca 21 öğrenci ile yürütülmüştür. STEM uygulamaları kapsamında öğrencilerden günlük yaşamdan bir problem belirleyerek canlılara ait yapı ve işlev arasındaki ilişkinin bir taklidi olabilecek biyomimikriyi kullanarak olası bir tasarım çözümü geliştirmeleri istenmiştir. Veriler, açık-uçlu sorular, yarı yapılandırılmış görüşmeler ve mühendislik sürecinin değerlendirilmesi için rubrik kullanılarak toplanmıştır. 
$\mathrm{Bu}$ çalışmada, öğrencilerin tasarladığı biyomimikri modellerine dayalı veriler, tasarım ve doğal dünyadan alınan ilham arasındaki ilişkilere dayalı olarak tasarım sürecinin bir analizi şeklinde sunulmuştur. Öğrencilerin geliştirdikleri biyomimikri modelleri göz önüne alındığında, öğrencilerin bir organizmayla ilgili yapı ve fonksiyon arasındaki tamamlayıcı ilişki yoluyla biyomimikriyi bir insanlık problemine yönelik tasarım çözümlerine yansıtmayı başardıklarını göstermektedir. Sonuç olarak, biyomimikri STEM etkinlikleri öğrencilerin mühendislik tasarım süreciyle ilgili deneyimler yaşarken canlıların adaptasyonlarını, yapı ve fonksiyon ilişkisine dayalı olarak daha iyi kavramsallaştırmalarını sağlamıştır. Öğrenciler biyomimikri tasarım sürecinde bazı zorluklar yaşamalarına rağmen, çoğu tasarım görevi ve model/prototip yapma dahil olmak üzere etkinlikle ilgili her şeyi beğendiklerini ifade etmişlerdir.

Doğanın sürdürülebilir tasarım çözümleri için bir model olarak kullanılması fen eğitiminde biyomimikrinin kavramsallaştırılmasını kaçınılmaz kılmaktadır. Biyomimikri, öğretmenlere yaşam bilimleri, STEM, yaratıcı problem çözme, tasarım ve sistem düşüncesini harmanlayarak her yaştan öğrencilere ilham verecek bir yol sunarak, eğitimde bir devrim olarak görülebilir (Biomimicry Institute, 2010). Biyomimikri, disiplinlerarası STEM'i sınıf ortamına entegre etme firsatı sağlaması açısından fen bilgisi öğretim programında yer almalıdır. STEM eğitiminde biyomimikriyi öğretmek doğayı; bilim, teknoloji, mühendislik ve matematikle kesiştirerek bütünleşik bir bağlam sağlayacaktır. Daha sürdürülebilir bir gelecek için, insan kaynaklı sorunların çözümünde öğrencilere ilham verecek biyomimikri stratejilerini öğretmek için daha fazla araştırmaya ihtiyaç vardır. 


\section{EK 1}

\section{Biyomimikri Tasarım Görevi}

Doğa uzun zamandır sanat, tasarım ve yenilik için bir ilham kaynağı olmuştur. Örneğin, uçma hayali kuran insanoğluna kuşların kanat yapıları en büyük yol gösterici olmuş ve bu sayede Wright kardeşler uçağı icat etmişlerdir. İnsanların ihtiyaç duyduğu problemlere doğadaki modelleri, sistemleri ya da canlılara ait farklı özellikleri taklit ederek tasarım çözümleri geliştiren bilim dalına Biyomimikri adı verilir. Biyomimikri uygulamaları günümüzde bilim, teknoloji, sanat, mimari, yapay zekâ, nanoteknoloji, robotik, endüstri, askeri araştırmalar, ulaşım gibi birçok alanda kullanılmaktadır.

Bir biyomimikri şirketi canlıların özelliklerini kullanarak insanların sorunlarına çözüm aramaktadır. $\mathrm{Bu}$ alanda yeni fikirlere ihtiyaç duyan şirket yetkilileri bir yarışma düzenler. Bir biyomimikri uzmanı olarak sizden beklenen; bitkilerin ve hayvanların sahip oldukları iç ve dış yapılarını büyümek, hayatta kalmak ve diğer tüm ihtiyaçlarını karşılamak için nasıl kullandıklarını taklit ederek insanlığın bir problemi için çözüm üretmenizdir.

Bu amaçla sizlerden takımınızla birlikte canlıların sahip oldukları yapıları gözlemlemeniz, bu yapıların işlevlerine ilişkin bilgi toplamanız sonra bu yapıları ve işlevleri kullanarak insanların bir problemini çözmek için tasarım yapmanız beklenmektedir.

Tasarımınızı tamamladıktan sonra yaptığınız çalışmayı bilim insanları ve mühendislerden oluşan bir kurula sunacaksınız. Sunumunuzda canlıya ait yapı ve bu yapının işlevini açıklayarak tasarımınızı nasıl oluşturduğunuzu, bunları insanların sorunlarını çözmek için nasıl kullandığınızı açılayacaksınız. Yarışma şartnamesi aşağıda verilmiştir:

\section{Yarışma Şartnamesi}

1- Tasarımınız bir canlıya ait en az bir yapının işlevini taklit ederek oluşturulmalıdır.

2- Tasarımınız insanların sorunlarından en az bir tanesine çözüm getirmelidir.

3- Tasarımınızda insan sağlığına zararlı madde kullanılmamalıdır.

4- Tasarımınızda geri dönüşüm malzemeleri başta olmak üzere her türlü malzemeyi kullanabilirsiniz.

**Tasarımınızda doğrudan gözlemleyerek ya da izlediğiniz belgesellerden, TÜBİTAK yayınları gibi okuduğunuz bilimsel kitaplardan canlıları, canlılara ait yapıları ve canlıların bu yapıları hayatta kalmak için nasıl kullandıklarını kanıta dayalı olarak belirleyeceksiniz. Bununla birlikte diğer kaynaklardan da (çevrimiçi sayfalar, ulaşabileceğiniz basılı kaynaklar) yararlanabilirsiniz.

Tasarım görevinizi gerçekleştirirken aşağıdaki mühendislik döngüsünü kullanacaksınız;

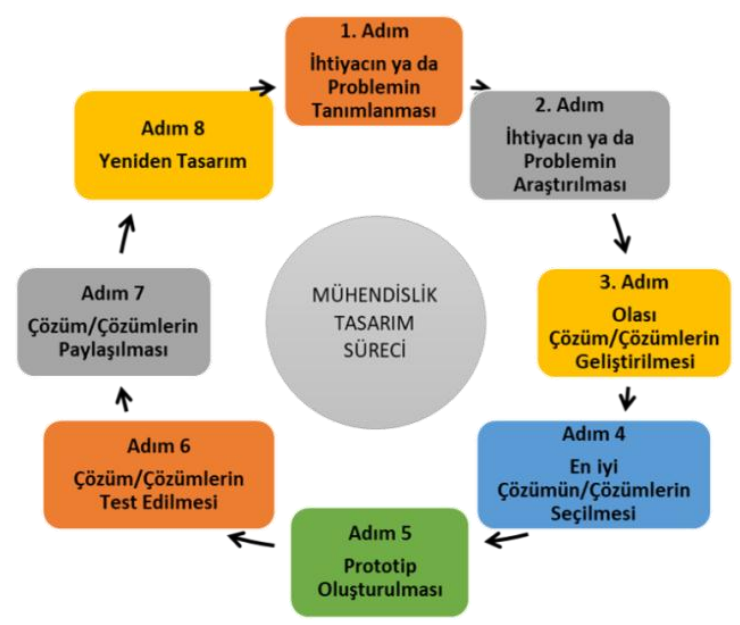




\section{EK 2}

\section{Yapı ve İşlev Çalışma Kâğıdı}

Adinız Soyadinız:

Okuduğunuz ve araştırdığınız kaynaklardan canlıların hayatta kalmasına yardımcı olan yapıları ve bu yapıların işlevlerini aşağıdaki tabloda özetleyiniz.

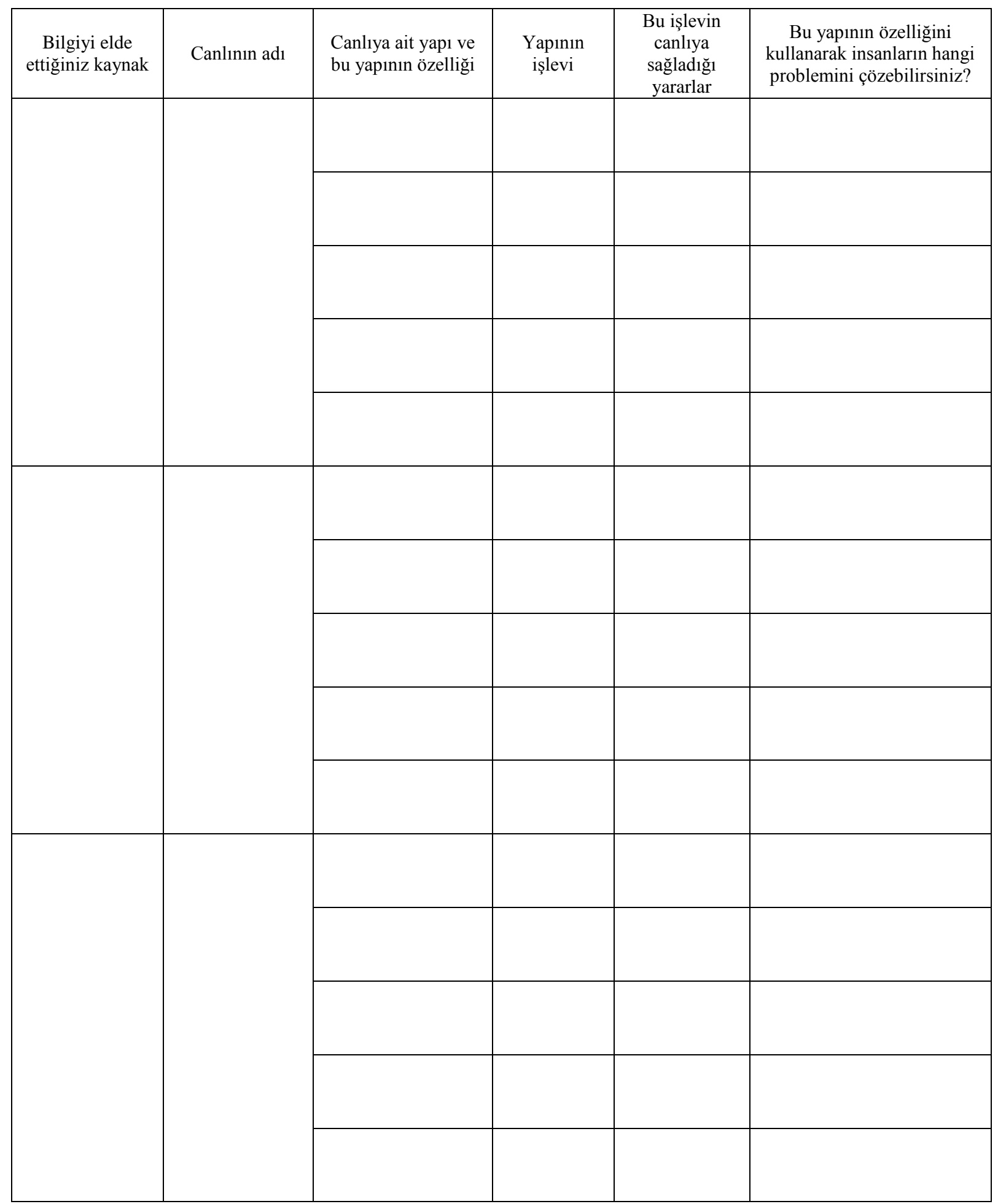




\section{EK 3}

\section{Hayali Canlının Adaptasyonları}

Takımınızın Adl:

Takım arkadaşlarınızla birlikte hayali bir canlı düşünün. Hayali canlının sahip olacağı özelliklere karar verirken her birinizin birinci aşamada bilgi sahibi olduğu farklı canlılara ait yapılar ve bu yapıların işlevlerini kullanabilirsiniz. Hayali canlınız için seçtiğiniz yapıları, yapıların işlevlerini ve canlıya sağladığı yararları aşağıdaki tabloyu kullanarak açıklayınız.

\begin{tabular}{|c|c|c|c|}
\hline Açıklamalar & $\begin{array}{l}\text { Yapının adı ve özelliği } \\
\text { (Kanat, kuyruk, ağız, } \\
\text { dişler, kök, yaprak, } \\
\text { hortum, göz, vb.) }\end{array}$ & Yapının işlevi & $\begin{array}{l}\text { Neden bu yapıyı seçtiğinizi } \\
\text { açıklayınız? } \\
\text { (Bu yapı canlınızın hayatta } \\
\text { kalması için ne tür bir yarar } \\
\text { sağlayacak?) }\end{array}$ \\
\hline $\begin{array}{l}\text { Canlınız hangi dış yapılara } \\
\text { sahip olacak? }\end{array}$ & & & \\
\hline $\begin{array}{l}\text { Canlınız hangi iç yapılara sahip } \\
\text { olacak? }\end{array}$ & & & \\
\hline $\begin{array}{l}\text { Canlınız besinlerini bulmak ve } \\
\text { yemek için hangi yapılara sahip } \\
\text { olacak? }\end{array}$ & & & \\
\hline $\begin{array}{l}\text { Canlınız düşmanlarından } \\
\text { korunmak için hangi yapılara } \\
\text { sahip olacak? }\end{array}$ & & & \\
\hline $\begin{array}{l}\text { Canlınız arkadaşlarıyla ve } \\
\text { yavrularıyla haberleşmek için } \\
\text { hangi yapılara sahip olacak? }\end{array}$ & & & \\
\hline $\begin{array}{l}\text { Canlınız eş bulmak için hangi } \\
\text { yapılara sahip olacak? }\end{array}$ & & & \\
\hline Siz de ekleyebilirsiniz... & & & \\
\hline
\end{tabular}




\section{EK 4}

\section{Hayali Canlının Çizimi ve Etiketlenmesi}

Takımınızın Adı:

Hayal ettiğiniz canlının resmini çiziniz. Resminizi çizerken hayal ettiğiniz canlıya ait yapıları detaylı olarak göstermeye dikkat ediniz.

Canlımızın bilimsel adı:

Canlınızı bilim dünyasına tanıtan bir hikâye ya da haber yazınız: 


\section{EK 5}

\section{Hayali Canlınızı Tanıtınız}

Takımınızın Adı:

Hayali canlınızı bilim dünyasına tanıtacaksınız. Bunun için aşağıdaki tür künyesini oluşturacaksınız. Bu künyede genel olarak canlınızın sahip olduğu yapılar ve özellikleri; bu özellikleri dikkate alarak bilimsel olarak ait olduğu grup, yaşam alanı, yuvası, besin kaynakları, düşmanları vb. yer verebilirsiniz.

\section{Canlımızın bilimsel adı:}

(İki isimden oluşan ikili isimlendirme adı verilen Latince bir isim olmalıdır. İlk isim cinsi, ikinci isim ise tür olarak tanımlanır. İsmin tamamı italik yazılmalıdır (ör., Homo sapiens) ve cins adının ilk harfi büyük büyük yazılarak kısaltılmalıdır (ör., H. sapiens).

Canlımızın ait olduğu grup:

Bitki-hayvan- mikroskobik canl1- mantar m1 olduğunu belirtiniz. Bitki ise çiçekli/çiçeksiz hayvan ise omurgalı/omurgasız mı? Omurgalı canlı ise memeli-balık-kurbağa-sürüngen-kuş mu? Omurgasız canlı ise böcek-örümceksolucan-salyangoz vb. mi? ya da birden çok gruba girebilir şeklinde özellikleriyle tanımlayınız.

\section{Canlımızın sahip olduğu vücut kısımları:}

(Kuyruk, kanat, hortum, ağız, gaga, yaprak, kök, bacaklar, kulaklar vb. şeklinde özellikleriyle tanımlayınız)

\section{Canlımızın yaşadığı yer:}

(Çöl/deniz/orman/kutuplar vb. şeklinde özellikleriyle tanımlayınız.)

Canlımızın yuvası ve özellikleri:

Canlımızın besin kaynağı:

Canlımızı bekleyen tehlikeler:

Canlımızın en güçlü özelliği:

Canlımızın en zayıf özelliği: 


\section{EK 6}

\section{Hayali Canlı Değerlendirme Rubriği}

Takım Adl:

\begin{tabular}{|c|c|c|c|c|c|}
\hline \multirow{2}{*}{ Boyut } & \multirow{2}{*}{ Kriter } & \multicolumn{4}{|c|}{ Hayali Canlı Değerlendirme Rubriği } \\
\hline & & 0 & 1 & 2 & 3 \\
\hline \multirow{3}{*}{$\begin{array}{l}\text { Model } \\
\text { geliştirme ve } \\
\text { kullanma }\end{array}$} & $\begin{array}{l}\text { Canlının } \\
\text { adlandırılm } \\
\text { as1 ve } \\
\text { sinıflandırıl } \\
\text { mas1 }\end{array}$ & $\begin{array}{l}\text { Canlı } \\
\text { adlandırılmamış ve } \\
\text { sinıflandırılmamıştır. }\end{array}$ & $\begin{array}{l}\text { Canlı } \\
\text { adlandırılmıştır fakat } \\
\text { sınıflandırılmamıştır. }\end{array}$ & $\begin{array}{l}\text { Canlı } \\
\text { sınıflandırılmış } \\
\text { fakat } \\
\text { adlandırılmamıştır. }\end{array}$ & $\begin{array}{l}\text { Canlı } \\
\text { adlandırılmış ve } \\
\text { sınıflandırılmıştır. }\end{array}$ \\
\hline & $\begin{array}{l}\text { Çizim ve } \\
\text { etiketleme }\end{array}$ & Canlı çizilmemiştir. & $\begin{array}{l}\text { Canlının çizimi net } \\
\text { değildir ve ince } \\
\text { detaylar eksiktir. }\end{array}$ & $\begin{array}{l}\text { Canlının çizimi } \\
\text { nettir fakat ince } \\
\text { detaylar eksiktir. }\end{array}$ & $\begin{array}{l}\text { Canlının çizimi } \\
\text { nettir ve ince } \\
\text { detaylara sahiptir. }\end{array}$ \\
\hline & Betimleme & $\begin{array}{l}\text { Canlı } \\
\text { betimlenmemiştir. }\end{array}$ & $\begin{array}{l}\text { Canlının } \\
\text { betimlemesi ile } \\
\text { çizim ile uyuşmuyor. }\end{array}$ & $\begin{array}{l}\text { Canlının } \\
\text { betimlemesi ile } \\
\text { çizimi tam olarak } \\
\text { uyuşmuyor. }\end{array}$ & $\begin{array}{l}\text { Canlının } \\
\text { betimlemesi ile } \\
\text { çizimi ile } \\
\text { uyuşuyor. }\end{array}$ \\
\hline \multirow{5}{*}{ Yapı ve İşlev } & Beslenme & $\begin{array}{l}\text { Yapı ve işlev } \\
\text { arasında bir ilişski } \\
\text { yoktur. }\end{array}$ & $\begin{array}{l}\text { Canlı modellenen } \\
\text { yapılarıyla besin } \\
\text { tüketemez. }\end{array}$ & $\begin{array}{l}\text { Canlı modellenen } \\
\text { yapilarıyla } \\
\text { güçlükle besin } \\
\text { tüketebilir. }\end{array}$ & $\begin{array}{l}\text { Canlı modellenen } \\
\text { yap1laryyla } \\
\text { kolayca besin } \\
\text { tüketebilir. }\end{array}$ \\
\hline & $\begin{array}{l}\text { Düşmanlard } \\
\text { an korunma }\end{array}$ & $\begin{array}{l}\text { Yapı ve işlev } \\
\text { arasında bir ilişsi } \\
\text { yoktur. }\end{array}$ & $\begin{array}{l}\text { Canlı modellenen } \\
\text { yapılarıyla } \\
\text { avc1larından } \\
\text { korunamaz. }\end{array}$ & $\begin{array}{l}\text { Canlı modellenen } \\
\text { yapılarıyla } \\
\text { avcılarından } \\
\text { güçlükle } \\
\text { korunabilir. }\end{array}$ & $\begin{array}{l}\text { Canlı modellenen } \\
\text { yapilariyla } \\
\text { avcilarından } \\
\text { kolayca } \\
\text { korunabilir. }\end{array}$ \\
\hline & Haberleşme & $\begin{array}{l}\text { Yapı ve işlev } \\
\text { arasında bir ilişki } \\
\text { yoktur. }\end{array}$ & $\begin{array}{l}\text { Canlı modellenen } \\
\text { yapılarıyla } \\
\text { haberleşemez. }\end{array}$ & $\begin{array}{l}\text { Canlı modellenen } \\
\text { yapılarıyla } \\
\text { güçlükle } \\
\text { haberleşebilir. }\end{array}$ & $\begin{array}{l}\text { Canlı modellenen } \\
\text { yapılarıyla } \\
\text { kolayca } \\
\text { haberleşebilir }\end{array}$ \\
\hline & Eş bulma & $\begin{array}{l}\text { Yapı ve işlev } \\
\text { arasında bir ilişki } \\
\text { yoktur. }\end{array}$ & $\begin{array}{l}\text { Canlı modellenen } \\
\text { yapılarıyla eş } \\
\text { bulamaz. }\end{array}$ & $\begin{array}{l}\text { Canlı modellenen } \\
\text { yapilarıyla } \\
\text { güçlükle eş } \\
\text { bulabilir. }\end{array}$ & $\begin{array}{l}\text { Canlı modellenen } \\
\text { yapilarıyla } \\
\text { kolayca eş } \\
\text { bulabilir. }\end{array}$ \\
\hline & Yaşam alanı & $\begin{array}{l}\text { Yapı ve işlev } \\
\text { arasında bir ilişski } \\
\text { yoktur. }\end{array}$ & $\begin{array}{l}\text { Canlı modellenen } \\
\text { yapılarıyla yaşam } \\
\text { alanında hayatta } \\
\text { kalamaz. }\end{array}$ & $\begin{array}{l}\text { Canlı modellenen } \\
\text { yapılarıyla yaşam } \\
\text { alanında güçlükle } \\
\text { hayatta kalabilir. }\end{array}$ & $\begin{array}{l}\text { Canlı modellenen } \\
\text { yapılarıla yaşam } \\
\text { alanında kolayca } \\
\text { hayatta kalabilir. }\end{array}$ \\
\hline Toplam Puan & $\ldots / 24$ & & & & \\
\hline
\end{tabular}




\section{EK 7}

\section{Büyük Tasarım Görevi Taslak Çizim}

Takımınızın Adl:

Üniteye başlarken size verilen büyük tasarım görevinizi tekrar okuyunuz. Bu aşamaya kadar öğrendiğiniz bilimsel bilgileri büyük tasarım göreviniz için uygulayacaksınız. Takımınızla birlikte oluşturacağınız tasarımınıza ilişkin olarak taslak çiziminizi aşağıya çizerek aşağıdaki soruları yanıtlayınız.

Tasarımınızı oluştururken hangi canlının yapı ve özelliğini kullandınız?

Tasarımınız insanların hangi sorununa nasıl çözüm üretecek?

Hangi malzemeleri tasarımınızın hangi bölümünde kullanacaksınız?

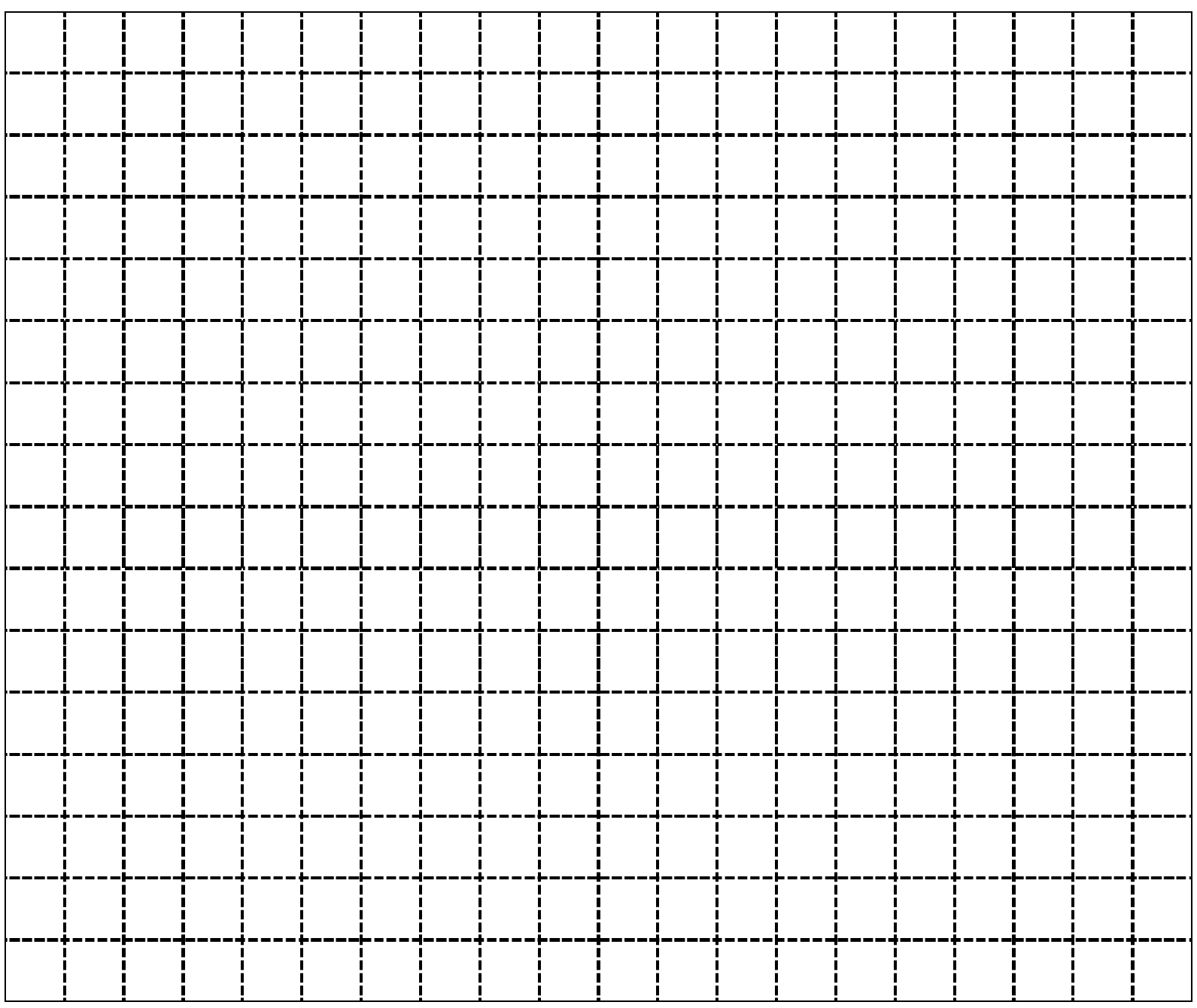




\section{EK 8}

\section{Biyomimikri Tasarım Görevi Değerlendirme Rubriği}

\begin{tabular}{|c|c|c|c|c|}
\hline $\begin{array}{l}\text { Mühendislik } \\
\text { Tasarım Süreci }\end{array}$ & 0 & 1 & 2 & 3 \\
\hline \multirow{2}{*}{$\begin{array}{l}\text { Problemin ya da } \\
\text { İhtiyacin } \\
\text { Tanımlanması }\end{array}$} & $\begin{array}{l}\text { İhtiyaç/problem } \\
\text { tanımlanmamış. }\end{array}$ & $\begin{array}{l}\text { İhtiyaç/problem yüzeysel } \\
\text { olarak tanımlanmış. }\end{array}$ & İhtiyaç/problem tanımlanmış. & $\begin{array}{l}\text { İhtiyaç/problem tüm } \\
\text { detaylarıyla açıç̧a } \\
\text { tanımlanmış. }\end{array}$ \\
\hline & $\begin{array}{l}\text { Kriterler ve kısıtlamalar } \\
\text { tanımlanmamış. }\end{array}$ & $\begin{array}{l}\text { Kriter ve kısıtlamaların } \\
\text { bir kısmı tanımlanmış. }\end{array}$ & $\begin{array}{l}\text { Kriter ve kısıtlamaların } \\
\text { çoğunluğunu tanımlanmış. }\end{array}$ & $\begin{array}{l}\text { Kriterler ve kısıtlamaların } \\
\text { tamamı tanımlanmış. }\end{array}$ \\
\hline \multirow{2}{*}{$\begin{array}{l}\text { Problemin ya da } \\
\text { İhtiyacın } \\
\text { Araştırılması }\end{array}$} & $\begin{array}{l}\text { İhtiyaç/problemin } \\
\text { çözümüne yönelik } \\
\text { gereksinim duyulan bilgi } \\
\text { belirlenmemiş. }\end{array}$ & $\begin{array}{l}\text { İhtiyaç/problemin } \\
\text { çözümüne yönelik } \\
\text { gereksinim duyulan } \\
\text { bilginin bir kısmı } \\
\text { belirlenmiş. } \\
\end{array}$ & $\begin{array}{l}\text { İhtiyaç/problemin çözümüne } \\
\text { yönelik gereksinim duyulan } \\
\text { bilginin çoğunluğu } \\
\text { belirlenmiş. }\end{array}$ & $\begin{array}{l}\text { İhtiyaç/problemin çözümüne } \\
\text { yönelik gereksinim duyulan } \\
\text { bilginin tamamı belirlenmiş. }\end{array}$ \\
\hline & $\begin{array}{l}\text { Elde edilen bilginin } \\
\text { insanların } \\
\text { ihtiyacını/problemlerini } \\
\text { çözmek için nasıl } \\
\text { kullanılacağ1 } \\
\text { belirlenmemiş. }\end{array}$ & $\begin{array}{l}\text { Elde edilen bilginin } \\
\text { insanların ihtiyacını / } \\
\text { problemlerini çözmek için } \\
\text { nasıl kullanılacağı } \\
\text { yüzeysel olarak } \\
\text { belirlenmemiş. }\end{array}$ & $\begin{array}{l}\text { Elde edilen bilginin insanların } \\
\text { ihtiyacın1/problemlerini } \\
\text { çözmek için nasıl kullanılacağı } \\
\text { belirlenmiş. }\end{array}$ & $\begin{array}{l}\text { Elde edilen bilginin insanların } \\
\text { ihtiyacını/problemlerini çözmek } \\
\text { için nasıl kullanılacağı tüm } \\
\text { detaylarıyla açıça } \\
\text { belirlenmemiş. }\end{array}$ \\
\hline \multirow[t]{2}{*}{$\begin{array}{l}\text { Olası Çözümlerin } \\
\text { Geliştirilmesi }\end{array}$} & $\begin{array}{l}\text { İhtiyaç/problemin } \\
\text { giderilmesine yönelik } \\
\text { çözüm önerisi } \\
\text { sunulmamış. }\end{array}$ & $\begin{array}{l}\text { İhtiyaç/problemin } \\
\text { giderilmesine yönelik } \\
\text { sunulan çözüm önerisi } \\
\text { kriterler ve kısıtlamaların } \\
\text { bir kısmı karş1lanmış. } \\
\end{array}$ & $\begin{array}{l}\text { İhtiyaç/problemin } \\
\text { giderilmesine yönelik sunulan } \\
\text { çözüm önerisi kriterler ve } \\
\text { k1sıtlamaların çoğunluğu } \\
\text { karşılanmış. }\end{array}$ & $\begin{array}{l}\text { İhtiyaç/problemin giderilmesine } \\
\text { yönelik sunulan çözüm önerisi } \\
\text { kriterler ve kısıtlamaların } \\
\text { tamamı eksiksiz karşılanmış. }\end{array}$ \\
\hline & $\begin{array}{l}\text { Çözüm önerisine yönelik } \\
\text { taslak çizilmemiş. }\end{array}$ & $\begin{array}{l}\text { Taslak çizim çözüm } \\
\text { önerisini yüzeysel olarak } \\
\text { yansıtmış. }\end{array}$ & $\begin{array}{l}\text { Taslak çizim çözüm önerisini } \\
\text { yansıtmış. }\end{array}$ & $\begin{array}{l}\text { Taslak çizim çözüm önerisini } \\
\text { tüm detaylarıyla yansıtmış. }\end{array}$ \\
\hline \multirow{2}{*}{$\begin{array}{l}\text { En İyi } \\
\text { Çözümlerin } \\
\text { Seçilmesi }\end{array}$} & $\begin{array}{l}\text { Çözüm önerilerinin } \\
\text { olumlu ve olumsuz } \\
\text { yönleri tanımlanmamış. }\end{array}$ & $\begin{array}{l}\text { Çözüm önerilerinin } \\
\text { olumlu ve olumsuz } \\
\text { yönlerini yüzeysel olarak } \\
\text { tanımlanmış. }\end{array}$ & $\begin{array}{l}\text { Çözüm önerilerinin olumlu ve } \\
\text { olumsuz yönlerini çoğunlukla } \\
\text { tanımlanmış. }\end{array}$ & $\begin{array}{l}\text { Çözüm önerilerinin olumlu ve } \\
\text { olumsuz yönleri tam ve } \\
\text { eksiksiz olarak tanımlanmış. }\end{array}$ \\
\hline & $\begin{array}{l}\text { Seçilen çözümün kriterleri } \\
\text { ve kısıtlamaları karşıllayıp } \\
\text { karşılamadığı } \\
\text { açıklanmamış. }\end{array}$ & $\begin{array}{l}\text { Seçilen çözüm için } \\
\text { gerekçelerin bir kısmı } \\
\text { açıklanmış. }\end{array}$ & $\begin{array}{l}\text { Seçilen çözüm için } \\
\text { gerekçelerin çoğunluğu } \\
\text { açıklanmış. }\end{array}$ & $\begin{array}{l}\text { Seçilen çözüm için gerekçelerin } \\
\text { tamamı detaylarıyla açıklanmış. }\end{array}$ \\
\hline \multirow[b]{2}{*}{$\begin{array}{l}\text { Prototip } \\
\text { Oluşturulması }\end{array}$} & $\begin{array}{l}\text { Çözüm önerisine yönelik } \\
\text { bir model / prototip } \\
\text { oluşturulmamış. }\end{array}$ & $\begin{array}{l}\text { Çözüm önerisine yönelik } \\
\text { kısmen uygun bir model / } \\
\text { prototip oluşturulmuş. }\end{array}$ & $\begin{array}{l}\text { Çözüm önerisine yönelik } \\
\text { uygun bir model / prototip } \\
\text { oluşturulmuş. }\end{array}$ & $\begin{array}{l}\text { Çözüm önerisine yönelik } \\
\text { tamamen uygun bir } \\
\text { model/prototip oluşturulmuş. }\end{array}$ \\
\hline & $\begin{array}{l}\text { Model/ prototip için kriter } \\
\text { ve kısıtlamaları karşılayan } \\
\text { malzeme kullanılmamış. }\end{array}$ & $\begin{array}{l}\text { Model/prototip için kriter } \\
\text { ve kısıtlamaları kismen } \\
\text { karşılayan malzeme } \\
\text { kullanılmış. }\end{array}$ & $\begin{array}{l}\text { Model/ prototip için kriter ve } \\
\text { kisıtlamaların çoğunluğunu } \\
\text { karş1layan malzeme } \\
\text { kullanılmış. }\end{array}$ & $\begin{array}{l}\text { Model/ prototip için kriter ve } \\
\text { kısitlamaların tamamını } \\
\text { karş1layan malzeme } \\
\text { kullanılmış. } \\
\end{array}$ \\
\hline \multirow{2}{*}{$\begin{array}{l}\text { Çözümlerin test } \\
\text { edilmesi ve } \\
\text { değerlendirilmesi }\end{array}$} & $\begin{array}{l}\text { Model/ prototipin ihtiyaci/ } \\
\text { problemi nasıl çözeceği } \\
\text { test edilmemiş. }\end{array}$ & $\begin{array}{l}\text { Model/ prototipin ihtiyacı } \\
\text { / problemi nasıl çözeceği } \\
\text { test edilmiş. Test } \\
\text { sonuçları analiz } \\
\text { edilmemiş. }\end{array}$ & $\begin{array}{l}\text { Model/ prototipin ihtiyacı / } \\
\text { problemi nasıl çözeceği test } \\
\text { edilmiş. Test sonuçları kısmen } \\
\text { analiz edilmiş. }\end{array}$ & $\begin{array}{l}\text { Model/prototipin ihtiyacı/ } \\
\text { problemi nasıl çözeceği test } \\
\text { edilmiş. Test sonuçlarının } \\
\text { tamamı analiz edilmiş. }\end{array}$ \\
\hline & $\begin{array}{l}\text { Test sonuçlarına ilişkin } \\
\text { veriler bilimsel bir dil } \\
\text { kullanılarak } \\
\text { açıklanmamış. }\end{array}$ & $\begin{array}{l}\text { Test sonuçlarına ilişkin } \\
\text { verilerin bir kısmı } \\
\text { bilimsel bir dil } \\
\text { kullanılarak açıklanmış. }\end{array}$ & $\begin{array}{l}\text { Test sonuçlarına ilişkin } \\
\text { verilerin çoğunluğu bilimsel } \\
\text { bir dil kullanılarak açıklanmış. }\end{array}$ & $\begin{array}{l}\text { Test sonuçlarına ilişkin } \\
\text { verilerin tamamı bilimsel bir dil } \\
\text { kullanılarak detaylarıyla } \\
\text { açıklanmış. }\end{array}$ \\
\hline \multirow[b]{2}{*}{$\begin{array}{l}\text { Çözümlerin } \\
\text { Paylaşılması }\end{array}$} & $\begin{array}{l}\text { Tasarımların ihtiyacı/ } \\
\text { problemi nasıl çözeceği } \\
\text { açıklanmamış. }\end{array}$ & $\begin{array}{l}\text { Tasarımların ihtiyacı/ } \\
\text { problemi nasıl çözeceği } \\
\text { kısmen açıklanmış. }\end{array}$ & $\begin{array}{l}\text { Tasarımların ihtiyacı/ } \\
\text { problemi nasıl çözeceği } \\
\text { açıklanmış. }\end{array}$ & $\begin{array}{l}\text { Tasarımların ihtiyacı/ problemi } \\
\text { nasıl çözeceği tam ve eksiksiz } \\
\text { açıklanmış. }\end{array}$ \\
\hline & $\begin{array}{l}\text { Canlı/canlılara ait } \\
\text { yap1/yapılar ve bu } \\
\text { yapıların } \\
\text { fonksiyonlarından ne } \\
\text { şekilde yararlanıldığ } \\
\text { belirtilmemiş. }\end{array}$ & $\begin{array}{l}\text { Canlı/canlılara ait } \\
\text { yapp/yapılar ve bu } \\
\text { yapıların } \\
\text { fonksiyonlarından ne } \\
\text { şekilde yararlanıldığı } \\
\text { kismen belirtilmiş. }\end{array}$ & $\begin{array}{l}\text { Canlı/canlılara ait yap1/yapılar } \\
\text { ve bu yapıların } \\
\text { fonksiyonlarından ne şekilde } \\
\text { yararlanıldığı belirtilmiş. }\end{array}$ & $\begin{array}{l}\text { Canlı/canlılara ait yapı/yapılar } \\
\text { ve bu yapıların } \\
\text { fonksiyonlarından ne şekilde } \\
\text { yararlanıldığı tam ve } \\
\text { detaylarıyla belirtilmiş. }\end{array}$ \\
\hline \multirow[b]{2}{*}{ Yeniden Tasarım } & $\begin{array}{l}\text { Tasarım için gerekli } \\
\text { iyileştirmeler } \\
\text { tanımlanmamış. }\end{array}$ & $\begin{array}{l}\text { Tasarım için gerekli } \\
\text { iyileştirmeler kısmen } \\
\text { tanımlanmış. }\end{array}$ & $\begin{array}{l}\text { Tasarım için gerekli } \\
\text { iyileştirmeler tanımlanmış. }\end{array}$ & $\begin{array}{l}\text { Tasarım için gerekli } \\
\text { iyileştirmeler detaylarıyla } \\
\text { tanımlanmış. }\end{array}$ \\
\hline & $\begin{array}{l}\text { Çözümlerin test edilmesi } \\
\text { ve paylaşılması sonucunda } \\
\text { elde edilen veriler ve geri } \\
\text { bildirimler doğrultusunda } \\
\text { tasarımlar } \\
\text { iyileştirilmemiş. }\end{array}$ & $\begin{array}{l}\text { Çözümlerin test edilmesi } \\
\text { ve paylaşılması } \\
\text { sonucunda elde edilen } \\
\text { veriler ve geri bildirimler } \\
\text { doğrultusunda tasarımlar } \\
\text { kısmen iyileştirilmiş. } \\
\end{array}$ & $\begin{array}{l}\text { Çözümlerin test edilmesi ve } \\
\text { paylaşılması sonucunda elde } \\
\text { edilen veriler ve geri } \\
\text { bildirimler doğrultusunda } \\
\text { tasarımlar iyileştirilmiş. }\end{array}$ & $\begin{array}{l}\text { Çözümlerin test edilmesi ve } \\
\text { paylaşılması sonucunda elde } \\
\text { edilen veriler ve geri bildirimler } \\
\text { doğrultusunda tasarımlar en iyi } \\
\text { şekilde iyileştirilmiş. }\end{array}$ \\
\hline Toplam Puan & $\ldots / 48$ & & & \\
\hline
\end{tabular}




\section{EK 9}

\section{Biyomimikri STEM Etkinliği Öğrenci Yansıtıcı Değerlendirme Formu}

Aşağıdaki soruları boşluklara cevaplayınız. Açıklamak için çizim ekleyebilirsiniz. Bunun için kâğıdın arka yüzünü veya ayrı bir kâğıt kullanabilirsiniz.

1. Modelinizi/prototipinizi tasarlarken ne tür zorluklarla karşılaştınız?

2. Bu zorlukların üstesinden nasıl geldiniz?

3. Çalışmada neler öğrendiniz?

4. Modelinizi/prototipinizi iyileştirmek için neler yaptınız?

5. Bu çalışmada neleri sevdiniz?

6. Bu çalışmada neleri sevmediniz?

7. Bir takım olarak nasıl çalıştığınızı açıklayınız?

8. Bu çalışmada neleri değiştirmek isterdiniz? 


\section{EK 10}

\section{Çizimler ve Oluşturulan Hayali Canlılar}

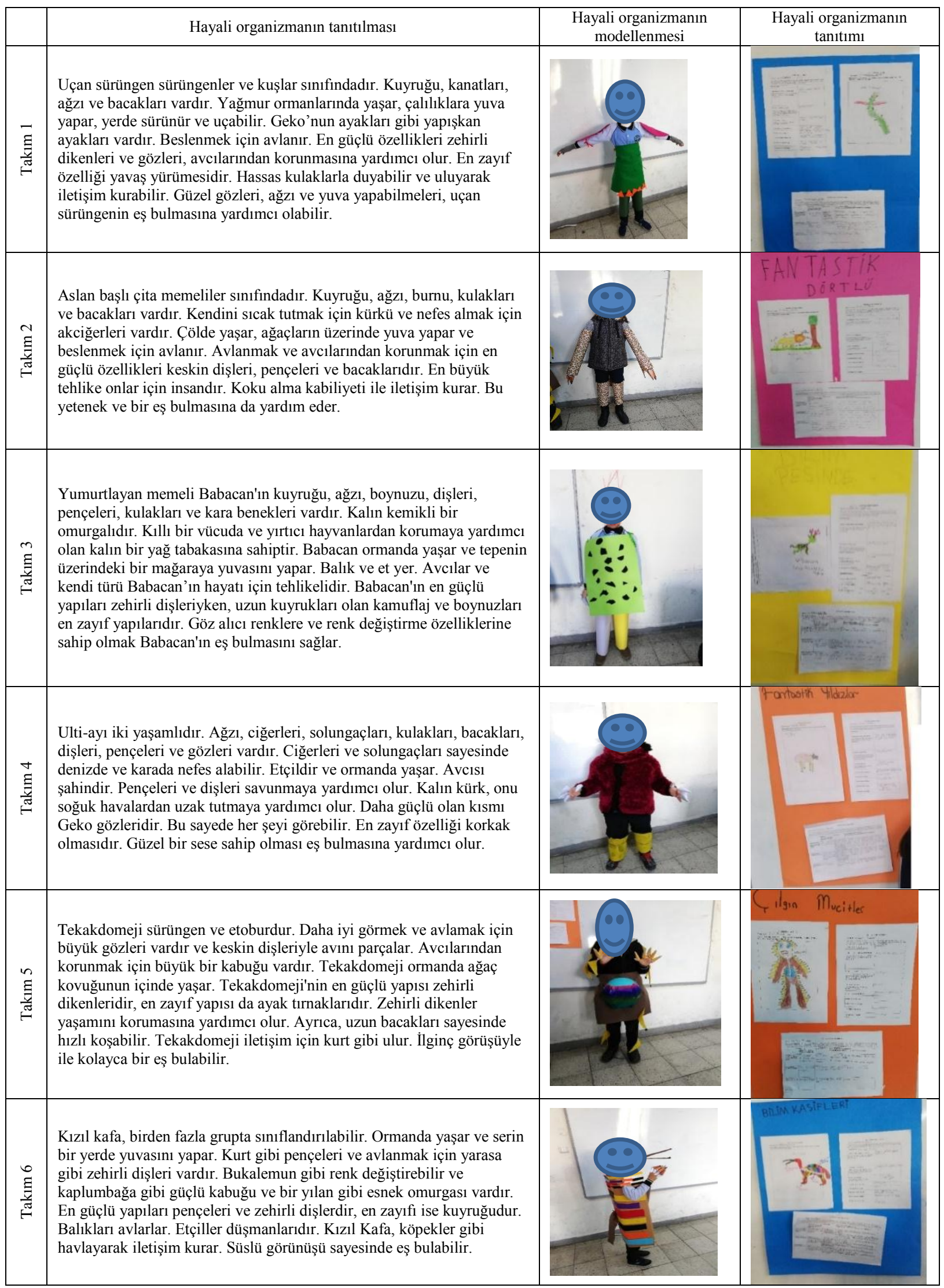




\section{EK 11}

\section{Büyük Tasarım Görevine Ait Taslak Çizimler}

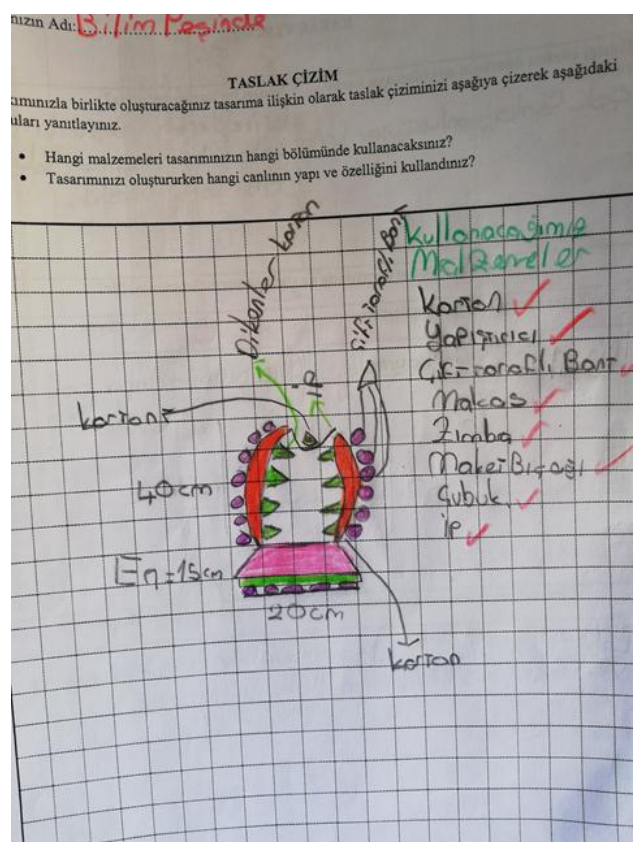

Takım 3

Tuzak Taslak Çizimi

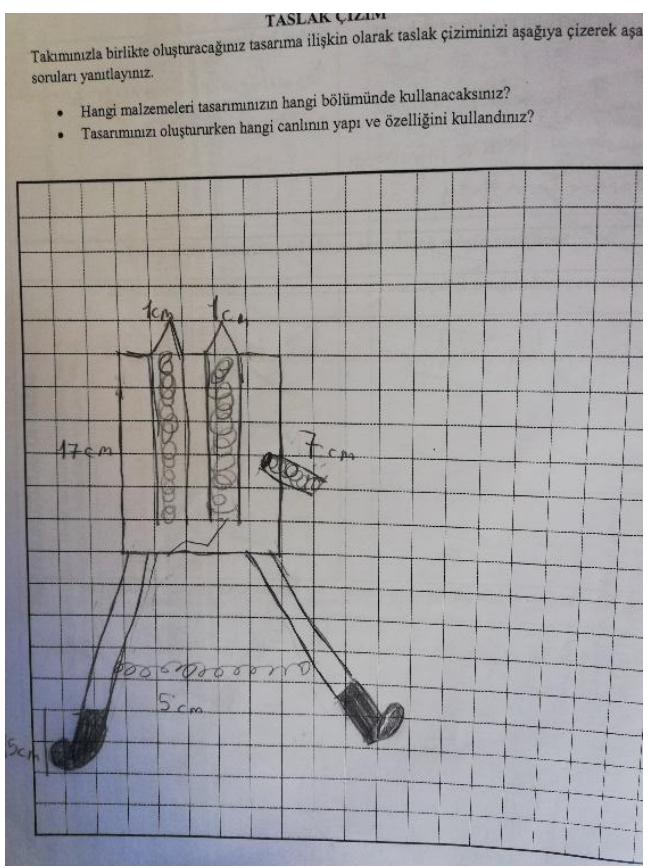

Takım 5

Diker-Gömer Taslak Çizimi

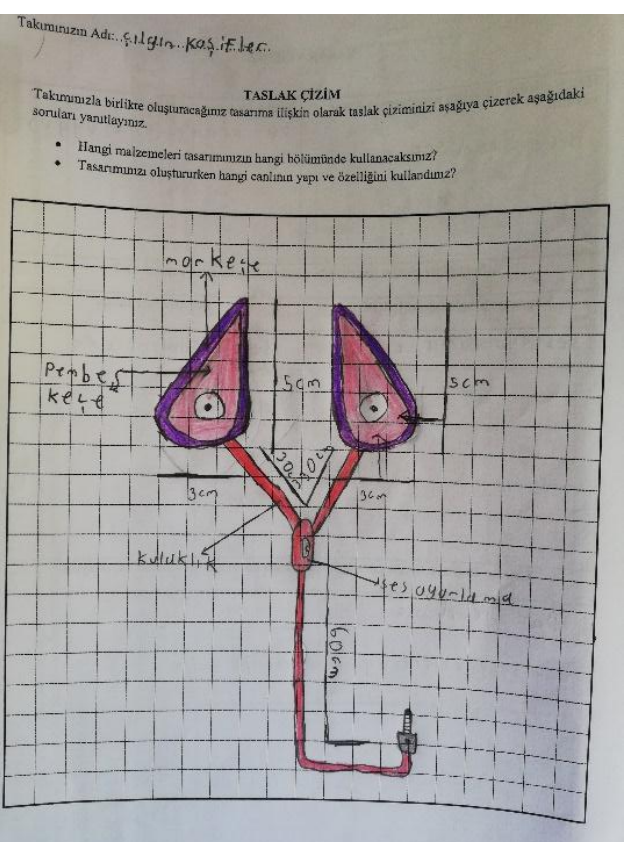

Takım 4

Yarasa Kulağından Kulaklık Taslak Çizimi

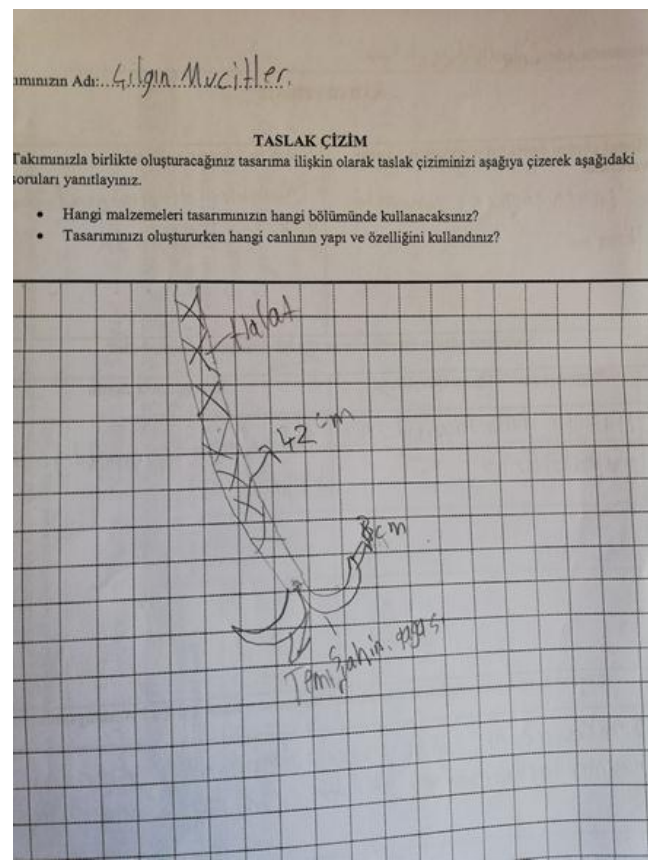

Takım 5

Kanca Taslak Çizimi 


\section{EK 12}

\section{Geliştirilen Biyomimikri Modelleri}

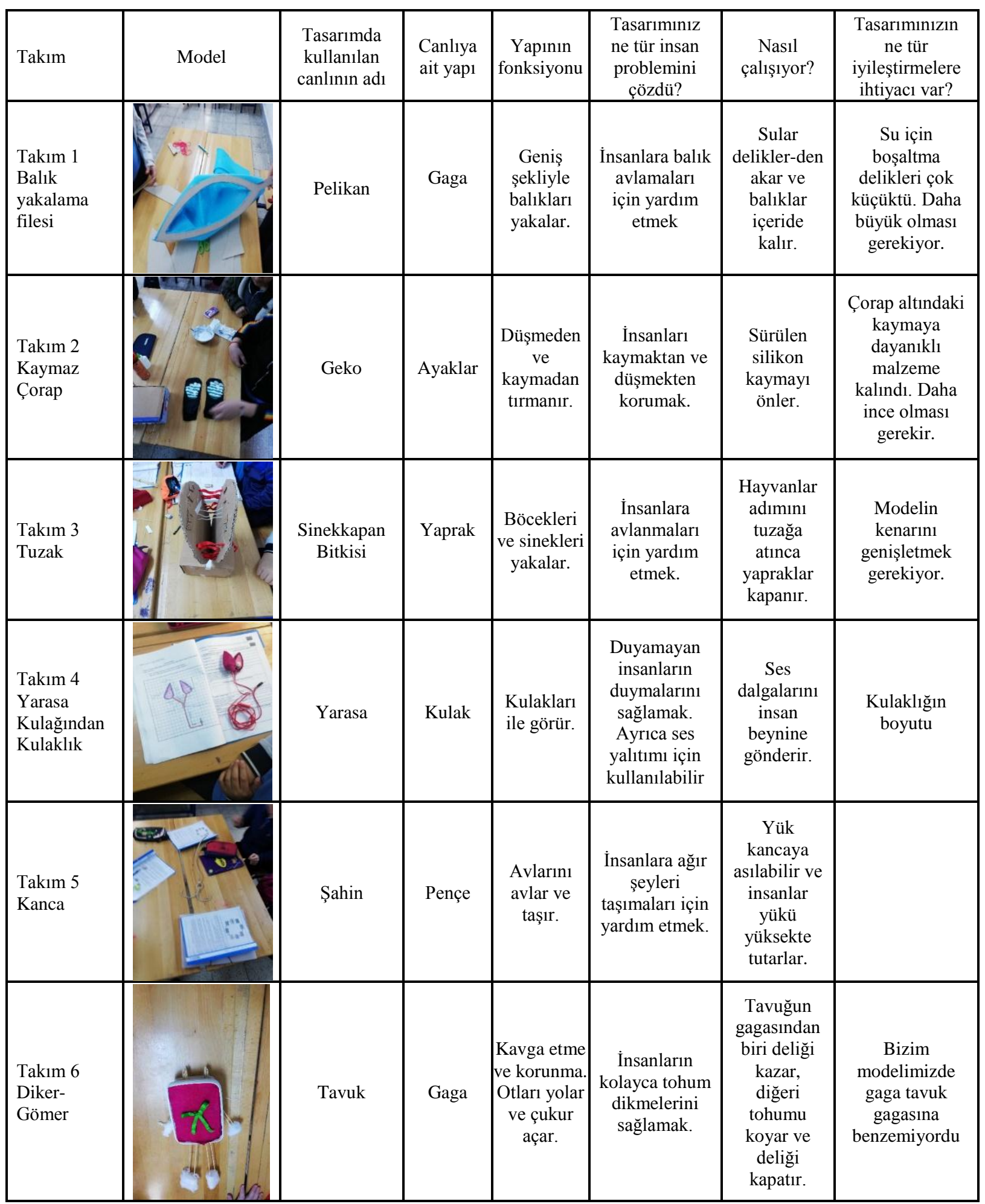

